\title{
2008 Küresel Finans Krizi Sonrasında Sermaye Kontrollerine Illişkin Tartışmalar
}

\author{
The Discussions on Capital Controls After The 2008 Global Financial Crisis
}

Cemil VARLIK*

\begin{abstract}
$\ddot{O} Z$
Bu çalışmada Küresel Kriz sonrası sermaye kontrollerine dair teorik ve ampirik literatürün gözden geçirilmesi amaçlanmaktadır. Küresel Kriz sonrasında ortaya çılkan teorik literatür, konjonktür karşıtı uygulanan ihtiyati sermaye kontrollerinin, makroekonomik ve finansal istikrarı artırabileceğini savunmaktadır. Aynı dönemde gelişen ampirik literatürde, sermaye kontrollerinin genellikle konjonktür karșıtı kullanılmadığı, fakat Kriz sonrası dönemde bazı ülkelerin kontrolleri konjonktür karşıtı biçimde uygulamayı başsardıkları tespit ediliyor. Ayrıca sermaye kontrollerinin hem ihtiyati hem de merkantilist amaçla kullanıldığı, fakat Kriz sonrasında ihtiyati güdünün payının arttığı bulgusuna ulaşıllyor. Çalışmaların çoğunda, sermaye kontrollerinin sermaye girișlerinin bileşimini değişstirmede, para politikası özerkliğini artırmada ve finansal kırılganlıkları hafifletmede etkili olduğu kanıtlanıyor. İlave olarak çok sayıda çalışma, kontrollerin sermaye girişlerinin hacmini ve döviz kuru baskıların azaltabileceğini buluyor. Diğer yandan, sermaye kontrollerinin diğer ülkeler üzerinde olumsuz yayllma etkilerine yol açabileceği gösteriliyor.
\end{abstract}

ANAHTAR KELIMELER

Sermaye Kontrolleri, Sermaye Akımları, Finansal İstikrar, Makroekonomik İstikrar

\begin{abstract}
The aim of this study is to review the theoretical and the empirical literature on capital controls after the Global Crisis. The theoretical literature emerged after the Crisis argues that prudential capital controls which are applied countercyclically may increase macroeconomic and financial stabilities. In the empirical literature developed during the same period, it is shown that capital controls have generally not used countercyclically, but in the post-crisis period, some countries have succeeded in implementing capital controls countercyclically. It is also found that capital controls have used for both prudential and mercantilist purposes, but the share of prudential motive has increased after the Crisis. In most of the articles, it is proven that capital controls are effective in changing the composition of capital inflows, enhancing monetary policy autonomy and mitigating financial vulnerabilities. In addition, many studies find that capital controls can reduce the volume of capital inflows and exchange rate pressures. On the other hand, it is shown that capital controls may cause adverse spillover effects on other countries.
\end{abstract}

\section{KEYWORDS}

Capital Controls, Capital Flows, Financial Stability. Macroeconomic Stability

\begin{tabular}{|c|c|c|}
\hline \multicolumn{2}{|r|}{$\begin{array}{c}\text { Makale Gelis Tarihi / Submission Date } \\
10.01 .2020\end{array}$} & $\begin{array}{c}\text { Makale Kabul Tarihi / Date of Acceptance } \\
\text { 03.07.2020 }\end{array}$ \\
\hline Atıf & $\begin{array}{l}\text { Varlik, C. (2020). } 2008 \text { Küresel } \\
\text { Üniversitesi Sosyal Bilimler Meslek }\end{array}$ & $\begin{array}{l}\text { Sermaye Kontrollerine İlişkin Tartışmalar. Selçuk } \\
\text { 2), 513-529. }\end{array}$ \\
\hline
\end{tabular}

\footnotetext{
* Doç.Dr., Ankara Hacı Bayram Veli Üniversitesi, İ̈BF, İktisat Bölümü, cemil.varlik@ @bv.edu.tr, ORCID 0000-0001-9977-2876.
} 


\section{GİRIŞ}

Gelişmekte olan ülkelerin sermaye hesaplarını hızla serbestleştirmeye başladıkları 1990'lı yıllar ve izleyen dönem, aynı zamanda bu ülkelerde finansal istikrarsızlığın da yaygınlaştığı dönem olmuştur (Reinhart ve Rogoff, 2009). Buna göre küresel sermaye piyasalarına entegre olan gelişmekte olan ülkeler, uluslararası sermaye akımlarındaki genişleme ve daralma çevrimlerine maruz kalmaktadırlar. $\mathrm{Bu}$ ülkeler genişleme safhasında sermaye girişleri yaşarken, daralma safhasında sermaye çıkışlarıyla ve sıkça sistemik finansal krizlerle karşılaşırlar. Genişleme dönemlerinde toplam talepteki artışa eşlik eden sermaye girişleri, yerli paranın değer kazanmasına ve yurtiçi aktif fiyatlarının artmasına yol açar. Yerli paranın değer kazanması ve aktif fiyatlarının artması, ekonomik birimlerinin bilançolarının iyileşmesine ve toplam talebin daha da artmasına sebep olur. Bu süreç, genişleme döneminde ortaya çıkan finansal genişletme etkisini tanımlar. Bir finansal kriz sırasında ise, ekonomi uluslararası sermaye piyasalarına girişini kaybeder ve bu yüzden toplam talep düşer. Böyle olunca yerli paranın değer kaybetmesi ve aktif fiyatlarının düşmesi, ekonomik birimlerin bilançolarının bozulmasına yol açar; bozulan bilançolar ise toplam talebin tekrar azalmasına sebep olur. $\mathrm{Bu}$ döngü ise, daralma döneminde yaşanan ters finansal genişletme etkisini tanımlar (Korinek, 2011).

Gelişmekte olan ülkelerde genişleme dönemlerinde sermaye girişlerinin artması ve olumsuz şoklar karşısında sermaye girişlerinin yavaşlaması, sermaye akımlarının konjonktürle aynı yönlü hareket ettiğini göstermektedir (Kaminsky vd., 2004). Sermaye akımları konjonktürle aynı yönde hareket ettiğinde, bu akımlar istikrar bozucu bir güç haline gelir. Sermaye hesaplarını serbestleştirmiş ekonomilerde sermaye akımlarının istikrar bozucu etkileri ise, önemli refah kayıpları yaratır. Küresel Kriz sonrasında Brezilya, Güney Kore ve Tayland gibi birçok gelişmekte olan ülke bu kayıplardan kaçınmak için, sermaye girişleri üzerine ihtiyati kontroller uygulamışlardır. Söz konusu ülkelerin bu uygulamaları, ihtiyati sermaye kontrollerinin refah artırıc1 etki yaratabileceğini savunan yeni teorik literatür tarafından desteklenmektedir (Bianchi ve Mendoza, 2010; Korinek, 2011; Bianchi, 2011; Jeanne ve Korinek, 2013; Benigno vd. 2013). Sermaye kontrollerine ilişkin bu yeni literatürde, finansal piyasa aksaklıkları altında finansal genişletme etkilerini yönlendiren döviz kurundaki ve aktif fiyatlarındaki değişmelerin, maddi dışsallıklara yol açtığı öne sürülmektedir. Söz konusu dışsallıkların, borçlanma ve teminat kısıtlamalarıyla karşı karşıya olan ekonomik birimlerin davranışlarında çarpıklıklara yol açtığı; bu çarpıklıkların da ekonomide aşırı borçlanmaya ve finansal kırılganlığa neden olduğu ifade edilmektedir. Bu yüzden, bir finansal kriz olmadan önce uygulanacak ihtiyati tedbirlerin, bireysel ajanların finansal kırılganlığa yaptıkları katkıyı içselleştirmelerine yol açarak refah artırıcı bir etki yaratacağı öngörülmektedir. Buna göre ihtiyati sermaye kontrolleri, ekonomik birimlerin borçlanmalarını azaltmak suretiyle, finansal kırılganlıkları ve finansal kriz olasılığını düşürecektir. Dolayısıyla yeni teorik literatürde, sermaye kontrollerinin konjonktür karşıtı uygulanması gerektiği öne sürülmektedir. Yani, sermaye girişlerindeki artışlara veya dünya faiz oranındaki düşüşlere tepki olarak kontrollerin konması ya da sıkılaştırılması; ardından sermaye girişleri durunca veya dünya faiz oranı yükselince kontrollerin gevşetilmesi önerilmektedir. Ayrıca yakın zamana kadar uluslararası finansal işlemlerin kısıtlanmasına karşı çıkan Uluslararası Para Fonu (IMF) da, artık sermaye kontrollerinin belirli koşullar altında makroekonomik ve finansal istikrarın sağlanması için kullanılabilecek meşru bir araç olduğunu kabul etmektedir (IMF, 2012).

Küresel Kriz sonrasında sermaye kontrollerine ilişkin teorik literatürün genişlemesine paralel olarak, ampirik çalışmaların da arttığı göze çarpmaktadır. Ampirik literatürde, teorik öngörülerin sınanması yanında, kontrollerin etkililiği ve diğer ülkelerde yarattıkları yayılma etkileri de araştırılmaktadır. Söz konusu ampirik çalışmalar, incelenen konu başlıklarına göre dört gruba ayrılabilir. Birinci gruptaki çalışmalar, sermaye kontrollerinin ihtiyati amaçla mı yoksa merkantilist amaçla mı uygulandığını araştırmaktadır (Pasricha, 2012; Pasricha, 2017). Bu çalışmalar, sermaye kontrollerinin hem ihtiyati hem de merkantilist amaçla kullanıldığını; fakat Küresel Kriz sonrası dönemde ihtiyati güdünün ön plana çıktığını göstermektedir. İkinci grupta, sermaye kontrollerinin konjonktür karşıtı kullanılıp kullanılmadığı sorusuna cevap arayan çalışmalar yer almaktadır (Eichengreen ve Rose, 2014; Fernandez, Rebucci \& Uribe, 2015; Gupta, 2018). Sözü edilen çalışmalarda, sermaye kontrollerinin genellikle konjonktür karşıtı kullanılmadı̆̆ı; fakat Kriz sonrası dönemde bazı ülkelerin sermaye kontrollerini konjonktüre karşı uygulamayı başardıkları gösterilmektedir. Üçüncü grup, sermaye kontrollerinin belirli hedeflere ulaşmada etkili olup olmadığını inceleyen çalışmalardan oluşmaktadır (Ahmed ve Zlate, 2014; Aizenman ve Binici, 2016; Bruno vd., 2017; Bruno ve Shin, 2014; Chamon ve Garcia, 2016; Dell Erba ve Reinhardt, 2015; Erten ve Ocampo, 2017; Forbes vd., 2015; Forbes vd., 2016; Ghosh vd., 2014; Jongwanich, 2019; Lambert vd., 2013; Li ve Rajan, 2015; Pasricha, 2018; Van der Lan vd., 2017; You vd., 2014; Zeev, 2017; Zhang ve Zoli, 2016). Bu gruptaki çalışmalar, sermaye kontrollerinin genellikle sermaye girişlerinin bileşimini değiştirmede, para politikasında özerkliği sağlamada ve finansal kırılganlıkları hafifletmede etkili olduğunu kanıtlamaktadır. Ayrıca birçok çalışmada kontrollerin, sermaye girişlerinin 
hacmini ve döviz piyasası baskısını azaltmada etkili olabileceği ispatlanmaktadır. Dördüncü gruptaki çalışmalar ise, sermaye kontrollerinin diğer ülkeler üzerinde yarattıkları yayılma etkilerini araştırmaktadır (Boero vd., 2019; Forbes vd., 2016; Giordani vd., 2017; Jongwanich, 2019; Lambert vd., 2013; Pasricha vd., 2018). Söz konusu çalışmalarda, genellikle sermaye kontrollerinin diğer ülkeler üzerinde olumsuz yayılma etkilerine yol açabileceği gösterilmektedir. Bu sonuçlar, sermaye kontrollerinin belirli hedeflere ulaşmak için etkili bir biçimde kullanılabileceğini; fakat kontrollerin yayılma etkilerinden doğan küresel refahı azaltıcı sonuçların hafifletilebilmesi için, ülkeler arasında politika koordinasyonuna gerek olduğunu göstermektedir.

Makalenin geri kalanı üç bölümden oluşacaktır. Birinci bölümde, Küresel Kriz sonrasında gelişen ve ihtiyati sermaye kontrollerinin refah artırıcı etki yaratabileceğini savunan yeni teorik literatür tanıtılacaktır. İkinci bölümde, Küresel Kriz sonrasında yapılmış olan sermaye kontrollerine ilişkin ampirik çalışmalarda elde edilen bulgulara yer verilecektir. Sonuç bölümünde yapılacak genel bir değerlendirme ile makale sonlandirılacaktır.

\section{SERMAYE KONTROLLERINE İLIŞKINN YENI TEORİK LITTERATÜR}

Sermaye kontrollerinin konjonktüre karşı kullanılmasını öneren çalışmalar, birinci en iyi politikaların uygulanmasının mümkün olmadığ 1 durumda, sermaye kontrollerinin ikinci en iyi müdahale biçimi olarak düşünülebileceğini savunurlar. Bu literatürün birinci kolu, nominal ücretlerin katı olduğu ve optimal olmayan para veya döviz kuru politikasının uygulandığı ekonomilerde, konjonktür karşıtı sermaye kontrollerinin, makroekonomik intibakı iyileştireceğini öngörür. Örneğin Schmitt-Grohe ve Uribe (2016), nominal ücretlerin katı olduğu ve sabit kur rejimi uygulayan bir ekonomiyi analiz etmektedir. Böyle bir ekonomide, sermaye girişlerinin olduğu dönemlerde, çıktı düzeyi artarken nominal ücretler de yükselecektir. Fakat sermaye akımlarında bir ani durma yaşanması durumunda, nominal ücretler -aşağı yönde katı olduğu için- yüksek düzeyinden geri düşmeyecek; sabit döviz kuru rejimi yüzünden bağımsız bir para politikasının uygulanması da mümkün olmayacaktır. Böyle olunca ekonomide işsizlik ortaya çıkacak ve çıktıda düşüş olacaktır. Nominal ücret çarpıklığını düzeltecek ya da döviz kurunu ve fiyat düzeyini doğrudan değiştirecek (birinci en iyi) politikaların uygulanmasının mümkün olmadığı böyle bir durumda, (sermaye girişi sırasında) sermaye kontrollerinin geçici olarak kullanılması ikinci en iyi politika olacaktır. Zira sermaye girişinin yaşandığı dönemde kontrollerin uygulanması, ücretlerdeki artışı yavaşlatacak ve sermaye girişinin durmasının ardından ortaya çıkacak işsizliğin de önüne geçilmesini sağlayacaktır. Böylece sermaye kontrolleri çıktıdaki dalgalanmaları da hafifletmiş olacaktır. Sermaye kontrollerinin konjonktür karşıtı biçimde geçici olarak kullanılmasının makroekonomik istikrarı artıracağı görüşü, Farhi ve Werning (2012) tarafindan da dile getirilmektedir. Buna göre, bir risk primi şoku karşısında sermaye kontrollerinin uygulanması, sermaye girişlerinin yavaşlamasını sağlayacaktır. Girişler üzerine konulan bir vergi, şokun yurtiçi nominal faiz oranı üzerindeki etkisini dengeleyerek, ekonomideki aşırı 1sınmayı önleyecektir. Böylece, çıktıdaki ve enflasyondaki dalgalanmaları hafifletmek suretiyle makroekonomik istikrarın sağlanmasına katkı yapacaktır.

Literatürün ikinci kolu ise, konjonktür karşııı sermaye kontrollerinin, finansal istikrarı artıracağını savunur (Bianchi ve Mendoza 2010; Korinek, 2011; Bianchi, 2011; Jeanne ve Korinek, 2013; Benigno vd. 2013). Buna göre, gelişmekte olan ülkelerin yaşadıkları genişleme ve daralma çevrimleri sırasında, finansal genişletme etkileri yaşanmaktadır. Finansal genişletme etkilerinin ortaya çıkmasının sebebi ise, olumsuz bilanço etkilerine yol açan finansal piyasa aksaklıklarıdır. Finansal genişletme literatüründe, finansal piyasalarda iki tür aksaklık olduğu vurgulanır. Birincisi, borçluların borçlanma kısıtına tabi olmalarıdır. Buna göre, gelişmekte olan ülkelerde ekonomik birimlerin borçları, gelirleri ile orantılı olarak artar veya azalır. Böyle olunca ekonomik genişleme safhasında gelirleri artan birimler, borçlanma kısıtları rahatladığı için daha fazla borç alabilirler. Ekonomide bir daralma başladığında ise, gelirdeki düşme nedeniyle borçlanma kısıtları daralır ve ekonomik birimler daha az borç alabilirler (Kiyotaki ve Moore, 1997; Mendoza, 2010). İkincisi ise, borçluların risk primi ile karşı karşıya olmalarıdır. Buna göre, ekonomik birimlerin borçları teminat kısıtlamasına tabidir. Ekonomik genişleme safhasında, net değerleri ve dolayısıyla teminat değerleri artan birimlerin risk primleri düşer ve bunlar daha fazla borç alabilirler. Ekonomik daralma ise, borçluların net değerlerinin düşmesine ve daha yüksek risk primine yol açar; böyle olunca ekonomik birimler daha az borçlanabilirler (Bernanke vd. 1999; Gertler vd. 2007).

Söz konusu aksaklıklar, genişleme safhasında finansal genişletme etkilerine, daralma safhasında ise ters finansal genişletme etkilerine neden olur. Toplam talepteki bir artış, yerli paranın değer kazanmasına ve aktif fiyatlarının artmasına yol açar; bu da ekonomik birimlerin bilançolarını olumlu etkiler. Böylece teminat değerleri arttığı ve borçlanma kısıtları rahatladığı için daha fazla borçlanan ekonomik birimler, harcamalarını artırırlar ve toplam talep daha da artar (finansal genişletme etkisi). Toplam talepteki bir düşüş ise, yerli paranın değer kaybetmesine ve aktif fiyatlarının düşmesine yol açar; bu da ekonomik birimlerin bilançolarını olumsuz

Selçuk Üniversitesi Sosyal Bilimler Meslek Yüksekokulu Dergisi, Yıl: 2020 Cilt: 23 Sayı:2 
etkiler. Böyle olunca, teminat değerleri düştüğü ve borçlanma kısıtları daraldığı için daha az borçlanan ekonomik birimler, harcamalarını kısarlar ve toplam talep daha da düşer (ters finansal genişletme etkisi). İște bu geri besleme döngüleri sonucunda, ekonomik şokların makroekonomik büyüklükler üzerindeki etkileri genişletilmiş olur.

İhtiyati sermaye kontrollerinin kullanılmasını öneren yeni literatür, yukarıdaki mekanizmada finansal genişletme (ve ters finansal genişletme) etkilerini yönlendiren döviz kurundaki ve aktif fiyatlarındaki değişmelerin, maddi dışsallıklara yol açtığını ve dışsallıkların da ekonomik birimlerin finansman ve harcama kararlarında çarpıklıklara neden olduğunu savunmaktadır (Korinek, 2011). Bu çarpıklıklar, genişleme dönemlerinde aşırı borçlanma biçiminde kendini gösterir. Buna göre, borçlanma kararlarını alırken döviz kurunu ve aktif fiyatlarını (dolayısıyla teminat değerlerini) veri olarak alan ekonomik birimler, sermaye girişi arttıkça, daha fazla borçlanırlar. Ancak ekonomik birimlerin bu bireysel davranışı, döviz kurundaki ve aktif fiyatlarındaki artışları besleyerek, ekonomide aşırı borçlanmaya yol açar (Engel, 2016). Bu süreçte piyasa katılımcıları, aşırı riskli ve kısa vadeli borçlanmaya yöneldiğinden, ekonomi aşırı düzeyde finansal kırılganlığa maruz kalır (Korinek, 2011). Daralma döneminde ise süreç tersine işler. Kısacası ekonomik birimler bireysel olarak, finansal (ve ters finansal) genişletmeye kendi katkılarını içselleştirmeyi başaramazlar. Böyle olunca, diğer katılımcılar üzerine daha fazla finansal istikrarsızlık biçiminde dışsallık yüklemiş olurlar. İşte yeni teorik literatürde, genişleme dönemlerinde dış borçlanma üzerine konulacak Pigou vergisi biçimindeki ihtiyati sermaye kontrollerinin, ekonomik birimlerin söz konusu dışsallıkları içselleştirmelerine yol açarak, finansal istikrarı artıracağı öngörülür (Korinek, 2011).

Bu noktada, yeni teorik literatürde ikinci en iyi politika olarak önerilen kontrollerin belli başlı özelliklerini vurgulamak yerinde olacaktır. Birincisi, yeni literatür ekonomik birimlerin aşırı risk alma güdülerini düzelteceği düşünülen ihtiyati sermaye kontrolleri üzerinde durmaktadır. Buradaki ihtiyati kavramı, bir finansal kriz olmadan önce, risklerin büyümesini engellemek için, sermaye girişleri üzerine konulan kontrolleri anlatmaktadır. İhtiyati sermaye kontrolleri, sermaye çıkışları üzerindeki kontrolleri veya ihtiyati motiflerin dışındaki kontrolleri kapsamaz (Korinek, 2011). Önerilen ihtiyati kontroller, aşırı borçlanma gibi piyasa çarpıklıklarının hafifletilmesine yönelik müdahalelerdir. Bunlar, yurtiçi aktiflerin yabancı alımlarını yasaklayan veya sinırlayan idari kontrollerden farklıdır (Engel, 2016).

İkincisi, diğer makro ihtiyati düzenlemeler değil, ihtiyati sermaye kontrolleri üzerinde durulmaktadır. Ekonomilerin sermaye akımlarının yarattığı finansal istikrarsızlı̆ın olumsuz etkilerinden korunması için, yurtiçi finansal işlemler üzerine getirilen makro ihtiyati düzenlemeler uygulanabilir. ${ }^{1}$ Ancak yüksek sermaye hareketliliğinin olduğu bir dünyada, sadece yurtiçi işlemlerin düzenlenmesiyle finansal kriz olasıllğ azaltılamaz. Makro ihtiyati düzenlemeler, yurtiçi ekonomik birimlerin aşırı borçlanmalarını önlemek için yeterli olmayabilir; çünkü borçlular, doğrudan yabancı bankalardan veya bunların yerli yan kuruluşlarından borç alabilirler (Engel, 2016). Ayrıca sermaye kontrollerinin makroekonomik etkisi, bankacılık düzenlemelerinden çok daha geniş kapsamlı olabilir (Jeanne, 2012). Makro ihtiyati düzenleme aktif fiyatları üzerinden işleyen maddi dışsallıklarla başa çıkılması için yeterli olsa da, döviz kuru üzerinden işleyen maddi dışsallıkların hafifletilebilmesi için sermaye kontrollerine de gerek duyulur (Korinek ve Sandri, 2016).

Üçüncüsü, sermaye kontrolleri, sermaye girişlerinin türüne göre farklılaştırılmalıdır. Buna göre, sistemik riski artıran akımlar üzerinde daha ağır kontroller olmalıdır (Jeanne, 2012; Korinek, 2011). Öyleyse kısa vadeli borç, uzun vadeli borca göre daha fazla kontrol altında olmalıdır. Ayrıca kontrollerin önceliği ve ağırlığı açısından doğru sıralama borç akımları, hisse akımları ve doğrudan yabancı yatırım (FDI) biçiminde olmalıdır. Diğer yandan, yeşil alan FDI'nın dışsallıklar yaratmadığı varsayılarak, bunlara yönelik kısıtlamalar veya vergiler önerilmez (Korinek ve Sandri, 2016).

Son olarak, yeni teorik literatürde sermaye kontrollerinin konjonktür karşıtı uygulanması gerektiği vurgulanmaktadır. Buna göre sermaye girişleri üzerindeki kontroller, genişlemeler sırasında sıkılaştırılmalı ve daralmalar sırasında gevşetilmelidir.

Bütün bu görüşler 1şığında Küresel Kriz sonrasında, sermaye kontrollerinin finansal istikrarın korunmasında önemli bir role sahip olabileceğini öngören yeni bir politika önerisi ortaya çıkmıştır. Son y1llarda IMF de, sermaye kontrollerinin finansal istikrar amacına ulaşmak için kullanılabilecek meşru bir politika aracı olabileceğini kısmen kabul etmeye başlamıştır. Buna göre sermaye kontrollerinin geçici bir şekilde ve en son çare olarak -sadece yeterli rezerv biriktirildikten, faiz oranlarında uyum sağlandıktan ve yerli paranın değer

\footnotetext{
${ }^{1}$ İhtiyati sermaye kontrolleri; sermaye akımlarının bileşimini, hacmini ya da etkilerini değiştirmeyi amaçlar. Diğer makro ihtiyati düzenlemeler ise, riskin yurtiçi ya da yurtdışı kaynaklı olmasından bağımsız olarak, sistemik finansal risklerin önüne geçmeyi amaçlar. Sermaye kontrollerinin ayırt edici özelliği, yatırımcıların yerleşikliğine göre belirlenmesidir. Yani sermaye kontrolleri, yerleşikler ile yerleşik olmayanlar arasındaki finansal işlemleri hedefler. Makro ihtiyati politikalar ise, krediyi verenin yerleşikliğinden bağımsız olarak, yurtiçi yerleşiklerin borçlanmalarını sınırlandırmayı hedefler (Korinek ve Sandri, 2016).
} 
kazanmasına izin verildikten sonra- uygulanması önerilmektedir (IMF, 2012). G20 ülkeleri de, ulusal ve uluslararası düzeyde finansal istikrarı ve sürdürülebilir büyümeyi tehdit eden oynak sermaye akımlarına karşı, sermaye hesabı düzenlemelerinin kullanılabileceğini kabul etmektedir $(G 20,2011)$.

\section{SERMAYE KONTROLLERINE İLIŞKINN YENI AMPİRIK LITERATÜR}

Son on yılda sermaye kontrollerine ilişkin teorik tartışmaların yeniden canlanmasına paralel olarak, konuya dair ampirik çalışmalar da artmaktadır. Söz konusu ampirik literatürde incelenen konular dört başlık altında toplanabilir. Birincisi, sermaye kontrollerinin ihtiyati amaçla $\mathrm{m} 1$ yoksa merkantilist amaçla $\mathrm{m} 1$ uygulandığı konusudur. İkincisi, sermaye kontrollerinin konjonktür karşıtı kullanılıp kullanılmadığı sorusudur. Üçüncüsü, sermaye kontrollerinin, belirli hedeflere ulaşmada etkili olup olmadığı hususudur. Dördüncüsü ise, sermaye kontrollerinin başka ülkeler üzerinde yaratması muhtemel yayılma etkilerinin araştırılmasıdır.

\subsection{Sermaye Kontrolleri İhtiyati mi Yoksa Merkantilist mi?}

Daha önce belirtildiği gibi, yeni teorik literatürde sermaye kontrollerinin ihtiyati amaçla kullanılması önerilmekte; genişleme dönemlerinde sermaye girişleri üzerine konulacak kontroller, optimal politika olarak görülmektedir.

Diğer taraftan sermaye kontrolleri, ihtiyati amaçlar dışında merkantilist amaçla da kullanılabilir. Merkantilist amaç, sermaye kontrollerinin (ve/veya rezerv birikiminin) kullanılmasıyla, yerli paranın düşük değerli tutulması ve bu yolla ihracatın teşvik edilmesidir (Dooley vd. 2004; Dooley vd. 2014; Pasricha, 2017). Son y1llarda birçok çalışmada, sermaye kontrolleri veya rezerv birikimi yoluyla yerli paranın reel olarak değerlenmesini önlemeye yönelik girişimlerin, aslında ihracat rakiplerine karşı rekabet avantajı sağlama amac1 taşı1ı̆̆ 1 öne sürülmektedir (Costinot vd. 2014; Dooley vd. 2014; Heathcote ve Perri, 2016). Dolayısıyla konjonktürün genişleme safhasında bir ülkede uygulanan sermaye kontrollerinin, sermayeyi başka ülkelere yönlendirebileceği; diğer ülkelerin de sermaye girişlerine benzer politika tepkisi vermesi durumunda ise (komşuyu fakirleştiren) bir para savaşının başlayabileceği dile getirilmektedir. Böyle bir para savaşının küresel düzeyde önemli refah kayıpları yaratacağı açıktır. O halde merkantilist amaçlı sermaye kontrollerinin, ihtiyati kontrollere göre daha fazla refah kayıplarına yol açabileceğini ve bu yüzden daha fazla kaygı yaratacağını söyleyebiliriz. Bu noktada sermaye kontrollerinin hangi amaçla kullanıldığı sorusunun önemi de ortaya çıkmaktadır. Bu yüzden merkantilist güdü ile uygulanan kontrolleri, ihtiyati güdü ile uygulanan kontrollerden ayırt etmek gerekir.

Pasricha (2017), 2001:W1-2015:W52 dönemi için 21 gelişmekte olan ülkenin haftalık verilerini kullanarak, sermaye kontrollerinin gerisindeki merkantilist ve ihtiyati güdüleri araştırmaktadır. Bu amaçla net sermeye girişleri üzerindeki kontrollerin bağıml değişken, merkantilist ve ihtiyati güdüleri temsil eden değişkenlerin de bağımsız değişkenler olduğu bir Logit model oluşturuluyor. Sermaye kontrolleri için merkantilist güdü, ülkenin en büyük beş ticari rakibinin paraları karşısında yerli paranın reel değer kazancı ile ölçülüyor. Söz konusu ticari rakipler de gelişmekte olan ülkeler oldukları için, bu ülkelerin para birimlerine karşı yerli paradaki değişmelerin ihtiyati güdüleri yansıtmayacağı, sadece merkantilist güdüleri yansıtacağ düşünülüyor. Çalışmada ihtiyati güdü için kullanılan temsili değişken ise, özel kesime verilen banka kredilerinin gayri safi yurtiçi hasılaya (GDP) oranıdır.

Logit modelin tahminlerine göre, merkantilist güdü değişkenindeki bir artış, ülkenin güçlü bir giriş kontrolü uygulama olasılığını artırıyor. Yani, ülkenin yerli parası ticari rakiplerinin parası karşısında reel olarak değer kazandığında, ülke sermaye kontrollerini sıkılaştırıyor. Ayrıca banka kredileri/GDP oranındaki bir artış, ülkenin güçlü bir giriş kontrolü uygulama olasılığını artırıyor. Pasricha (2017)'ya göre bu bulgular, ele alınan dönemde gelişmekte olan ülkelerin giriş kontrollerinin, hem merkantilist hem de makro ihtiyati kaygılara sistematik olarak tepki verdiğini gösteriyor. Çalışmada ayrıca, Küresel Kriz sonrasında sermaye kontrollerinin kullanımında makro ihtiyati faktörlerin ağırlı̆̆ının arttığı sonucuna ulaşı1ıyor.

Pasricha (2012) çalışması da, Küresel Kriz sonrasında ihtiyati olmayan tedbirlerden ihtiyati tedbirlere doğru bir kayma olduğunu buluyor. Yazar, ihtiyati tedbirlerin payındaki bu artışı, ihtiyati kontrollerin saf sermaye kontrollerinden daha az çarpıtıcı olduğu varsayımı altında, finansal istikrar açısından olumlu bir eğilim olduğunu düşünüyor. Adı geçen çalışmada ayrıca, sermaye kontrollerinin IMF'nin önerdiği gibi en son çare olarak kullanılıp kullanılmadığı da araştırılıyor. Ele alınan dönemde, sermaye kontrollerinin en son çare olarak uygulanmadığ1; kontrol uygulayan ülkelerin çoğunda, net sermaye girişlerindeki artışla başa çıkmak için kullanılabilecek en az bir alternatif makroekonomik politika seçeneği olduğu tespit ediliyor. 


\subsection{Sermaye Kontrolleri Konjonktür Karşıtı Kullanılıyor mu?}

Önceki bölümde açıklandığı gibi, sermaye kontrollerine ilişkin yeni teorik literatürde, sermaye kontrollerinin konjonktür karşıtı uygulanması gerektiği savunulmaktadır. Bu noktada yeni literatürün teoriye dayanan bu önerisinin, uygulamada ne ölçüde kullanıldığı sorusu akla gelmektedir. Eğer sermaye kontrolleri konjonktür karşıtı biçimde kullanılıyorsa, kontrollerin konjonktür dalgalanmaları sıklığında değiştiriliyor olmasi gerekir.

Hükümetlerin sermaye kontrollerini konjonktür karşıtı biçimde uygulayıp uygulamadığını araştıran çalışmalardan biri, Eichengreen ve Rose (2014) çalışmasıdır. Bu çalışmada IMF'nin sermaye kontrollerine ilişkin verileri (AREAER) kullanılarak 1996-2012 dönemi incelenmektedir. İlk olarak, 1996 y1lında 169 ülkenin 127 tanesinin sermaye kontrolü uyguladığı, 2012 yılına gelindiğinde ise hala 116 ülkenin bu tür kontrollere sahip oldukları belirleniyor. Bu sonuç, sermaye kontrollerinin büyük ölçüde kalıcı olduğu ve zaman içinde çok yavaş değiştiği biçiminde yorumlanıyor. İkinci olarak, panel regresyon analiziyle, ele alınan dönemde sermaye kontrolleri ile döviz kuru rejimi arasında zayıf bir ilişki tespit ediliyor. Bu sonucun, sermaye kontrollerinin bağımsız bir para politikası için ikinci en iyi ikame olduğunu savunan teorik görüşe uygun olmadığı belirtiliyor. Zira döviz kuru sabitlendiğinde kontrolleri koyan ve sürdüren ülkelerin, genel olarak, sabit kur rejimi terk edildiğinde bunları hızla ortadan kaldırmadığı anlaşılıyor. Ayrıca sermaye kontrolleri ile finansal krizler arasında daha da zayıf bir ilişki tespit ediliyor. Bu sonucun, kontrollerin birinci en iyi ihtiyati politikalar karşısında ikinci en iyi politika olduğu yönündeki teorik düşünceye uygun olmadığı belirtiliyor. Zira kontrollerin, finansal istikrarsızlığa ve finansal krizlere tepki olarak nadiren ayarlandığı anlaşılıyor. Üçüncü olarak, sermaye kontrolleri ile enflasyon, büyüme oranı, diş ticaret hadleri, sermaye hesabı/GDP oranı ve yurtiçi kredi büyümesi arasında zayıf bir ilişki bulunuyor. Dolayısıyla hükümetlerin, çıktıdaki kısa vadeli dalgalanmalara, ticaret koşullarına veya finansal istikrar kaygılarına tepki olarak nadiren sermaye kontrolleri uyguladıkları veya kaldırdıkları sonucuna ulaş1lıyor. Son olarak, sermaye kontrolleri ile finansal, politik ve kurumsal gelişmişlik düzeyleri arasında negatif ve anlamlı bir ilişki bulunuyor. Yani ülkelerin finansal, politik ve kurumsal gelişmişlik düzeyi arttıkça, kontroller gevşetiliyor ya da kaldırılıyor. Sonuç olarak, hükümetlerin sermaye kontrollerini iş çevrimi sıklığında ayarlayabildiklerine dair çok az kanıt bulunuyor. Bu yüzden yazarlar, hükümetlerin birinci en iyi politika araçlarını geliştirmeye odaklanmaları ve sermaye kontrollerini sadece son çare olarak görmeleri gerektiğini savunuyorlar.

Fernandez, Rebucci \& Uribe (2015) çalışması da, ekonomik faaliyetteki genişlemelerin ve daralmaların, sermaye kontrollerindeki hareketlere eşlik etmediğini buluyor. Adı geçen makalede, 91 ülkenin 1995-2011 dönemine ait yıllık verileri kullanılıyor. Çalışmanın birinci bulgusu, sermaye kontrollerinin konjonktürel bileşeninin koşulsuz standart sapmasının küçük olduğu biçimindedir. Bu sonuç, politika yapıcıların sermaye kontrollerini, konjonktür dalgalanmaları karşısında değiştirmediği biçiminde yorumlanıyor. İkinci bulgu, sermaye giriş ve çıkış kontrollerinin konjonktürel bileşenlerinin pozitif ilişki içinde olduğudur. Bu sonucun $\mathrm{da}$, sermaye kontrollerinin bir istikrar aracı olarak kullanılmadığını gösterdiği savunuluyor. Zira net sermaye girişleri üzerindeki kontrollerin istikrar amacıyla kullanılması durumunda, politika yapıcıların genişlemeler sırasında giriş kontrollerini artırması ve çıkış kontrollerini azaltması; daralmalar sırasında ise tersinin geçerli olması beklenirdi. Bu durumda giriş ve çıkış kontrolleri arasında negatif korelasyon olurdu. Üçüncü ve en önemli bulgu, ekonomide makroekonomik genişlemeler ve daralmalar sırasında sermaye kontrollerinin davranışı incelenince ortaya çıkıyor. Genişleme ve daralma safhaları, üç farklı makroekonomik göstergeyle belirleniyor: çıktı açığı, reel efektif döviz kurunun konjonktürel bileşeni ve cari işlemlerin konjonktürel bileşeni. Sermaye giriş ve çıkış kontrollerinin, makroekonomik genişlemeler ve daralmalar sırasında (ortalama olarak) değişmeden kaldığı bulunuyor. Buna göre, son 15 yılda sermaye kontrollerinin sistematik biçimde konjonktür karşıtı olarak uygulanmadığı sonucuna varılıyor. Üstelik bu sonuçların kalkınma düzeyi, dış borç düzeyi ve döviz kuru rejimi kontrol edildiğinde de değişmediği ve son Küresel Kriz sırasında da geçerli olduğu ifade ediliyor.

Gupta ve Masetti (2018) çalışmasında, 47 gelişen piyasa ekonomisinin 1999:Q1-2016:Q2 dönemine ait verileri kullanılarak panel regresyon analizi yapılıyor. Makalede yurtiçi GDP'nin, reel kredilerin, sermaye akımlarının ve G7 ülkelerinin GDP'lerinin konjonktürel bileşenleri ile sermaye kontrolleri arasında anlamlı bir ilişki olmadığı gösteriliyor. Buna göre kontrollerin yurtiçi iş çevrimlerinin, uluslararası likidite çevrimlerinin ve sermaye akımı şoklarının etkilerini hafifletmek için aktif bir politika aracı olarak kullanılmadığı ifade ediliyor. Ayrıca sermaye akımlarının farklı bileşenlerine yönelik kontrollerin de, konjonktür sıklığında nadiren değiştirildiği belirleniyor. Kontroller kullandığı zaman da; yerleşik olmayanların akımları yerine yerleşiklerin akımları üzerindeki kısıtlamaların; doğrudan yatırım veya bankacılık akımlarına uygulanan kısıtlamalardan çok portföy akımları üzerindeki kısıtlamaların değiştirildiği tespit ediliyor. 
Sonuç olarak, sermaye kontrollerinin konjonktürel özelliklerini inceleyen üç çalışmada da, bu kontrollerinin genellikle konjonktüre karşı uygulanmadığı bulgusuna ulaşılıyor. Yine de bu kuralın bazı istisnalarının olduğu; az sayıda ülkenin sermaye girişi sırasında sermaye kontrollerini sıkılaştırarak ve girişler azaldığında bunları gevşeterek, kontrolleri konjonktür karşıtı düzenlemeyi başardığı da kabul ediliyor (Eichengreen ve Rose, 2014; Fernandez, Rebucci \& Uribe, 2015). Buna göre Brezilya, Endonezya, Tayland ve Güney Kore, Küresel Kriz sonrasında sermaye hareketleri karşısında kontrollerin sıkılaştırılıp gevşetildiği istisnai örneklerdir. Yazarlara göre kontrolleri konjonktür sıklığında ayarlayabilmek için, kontrol uygulanacak olan finansal işlemlerin izlenmesini sağlayacak sistemlere gerek duyulur. Yakın geçmişte kontrol uygulamış olan ya da hâlihazırda kontrol uygulayan ülkeler bu sistemlere sahip olacak; dolayısıyla bu ülkeler için sermaye kontrolü uygulamak daha kolay ve daha az maliyetli olacaktır. Yukarıda adı geçen ülkelerin kontrolleri konjonktür sıklığında değiştirmeyi başarmış olmalarının sebebi, bu ülkelerin ilgili sistemlere halihazırda sahip olmalarıdır (Eichengreen ve Rose, 2014).

\subsection{Sermaye Kontrolleri Etkili mi?}

Daha önce açıklandığı gibi, yeni teorik literatürde sermaye girişleri üzerine uygulanan kontrollerin, aşırı borçlanmayı önleyerek dışsallıklarla başa çıkması beklenmektedir. Dolayısıyla kontrollerden beklenen refah kazancının elde edilebilmesi için, bunların sermaye girişlerinin hacmini azaltması ve/veya bileşimini uzun vade lehine değiştirmesi gerekir. Bu makalede esas olarak Küresel Kriz sonrası dönemde sermaye kontrollerine ilişkin yapılan ampirik çalışmalar ele alınıyor olsa da, Kriz öncesi dönemdeki literatürün sonuçlarını da özetlemekte yarar vardır. ${ }^{2}$ Küresel Kriz öncesinde yapılan çok ülkeli çalışmalarda genellikle sermaye kontrollerinin, net sermaye akımlarının toplam hacmi üzerinde sınırlı etkisi olduğu, fakat sermaye akımlarının bileşimi üzerinde önemli etkilere sahip olabileceği tespit ediliyor. Diğer taraftan sermaye kontrolleri, ihtiyati amaçlar dışında yerli paranın reel değer kazancını önlemek ve parasal otonomiyi korumak amacıyla da uygulanabilir. Küresel Kriz öncesinde yapılan çalışmalarda, genellikle sermaye kontrollerinin para politikasını daha bağımsız hale getirdiği gösterilse de, reel döviz kuru üzerindeki etkilere dair bulgular açık değildir. Örneğin Magud vd. (2011), giriş kontrollerinin reel döviz kuru üzerindeki baskıları azalttığı bulgusuna ulaşırken; Baba ve Kokenyne (2011), kontrollerin döviz kuru baskısını azalttığına dair çok fazla kanıt bulamiyor.

Küresel Kriz sonrasında sermaye kontrollerinin etkililiğini araştıran çalışmalarda, genellikle net akımlar yerine brüt akımlara ait veriler kullanılmaktadır. Brüt akımlar, varlığın sahibinin yabancı mı yoksa yerleşik mi olduğuna göre belirlenir. ${ }^{3}$ Ayrıca sermaye akımlarının toplam hacmi yanında bileşenleri üzerindeki etkiler de incelenmektedir. Örneğin, portföy girişleri ve FDI girişleri üzerindeki etkiler ayrı ayrı ele alınmaktadır. Sermaye akımlarının alt bileşenleri (borç senedi girişleri, hisse senedi girişleri ve bankacılık girişleri gibi) de ayrı ayrı dikkate alınabilmektedir. Nihayet belirli bir ülkede uygulanan sermaye kontrollerinin etkilerini inceleyen araştırmalar yanında, çok ülkeli çalışmalar da mevcuttur.

Belirli bir ülkedeki sermaye kontrollerinin etkilerini araştıran çalışmalarda en çok Brezilya örneği ele alınmaktadır. Zira Küresel Kriz sonrasında sermaye kontrollerini konjonktür karşıtı olarak en aktif biçimde kullanan ülkelerden birisi Brezilya'dır (Chamon ve Garcia, 2016). Kriz sonrasında Amerikan Merkez Bankası'nın (FED) tahvil alım programlarını devreye sokmasının ardından, piyasalara verilen doların bir kısmı gelişmekte olan ülkelere yönelmiştir. Söz konusu dönemde aşırı sermaye girişlerinin olumsuz etkilerinden çekinen Brezilya, 2009 yılında hisse senedi ve sabit getirili kıymetlere yönelik portföy girişlerine $\% 2$ vergi uygulamaya başlamış; sabit getirili kıymetler üzerindeki vergi oranı 2010 yılında önce \%4'e daha sonra da \%6'ya kadar yükseltilmiştir. 2011 yılının Mart ayında ise vadesi bir yıla kadar olan dış kredilere (banka kredileri ve yurtdışında ihraç edilen bonolar) $\% 6$ işlem vergisi getirilmiş; bu vergi bir yıllık süre içerisinde vadesi beş yıla kadar olan dış kredilere de uygulanmaya başlamıştır. Söz konusu tedbirlere ilave olarak, 2011 yılının Haziran ayında bankaların brüt döviz pozisyonlarına faizsiz rezerv zorunluluğu getirilmiş ve Temmuz ayında türev araçların önemli bir kısmına da vergi uygulanmıştır. Kısacası, sermaye girişlerinin yoğun olduğu 2012 yılının ortalarına kadar sermaye kontrolleri artırılmıştır. Bu tarihten itibaren sermaye girişlerinin yavaşlamasıyla birlikte sermaye kontrolleri de gevşetilmeye başlamıştır. \%6 vergi oranının uygulandığı dış

\footnotetext{
${ }^{2}$ Küresel Kriz öncesinde sermaye kontrollerinin etkilerine dair ampirik literatür taraması için, Cardoso ve Goldfajn (1998), Montiel ve Reinhart (1999), Ostry vd. (2010), Magud vd. (2011) ve Baba ve Kokenyne (2011) çalışmalarına bakılabilir.

${ }^{3}$ Brüt sermaye girişleri, yerleşik olmayanların yurtiçi varlık alım ve satımlarının netidir ve dış yükümlülük stokundaki değişimi ölçer. Brüt çıkışlar ise, yerleşiklerin yabancı varlık alım ve satımlarının netidir ve dış varlık stokundaki değişimi ölçer. Net akımlar ise, brüt girişler ile brüt çıkışlar arasındaki farktır. Sermaye kontrolleri, brüt girişleri veya brüt çıkışları hedefleyebilir. Giriş kontrolleri, brüt girişleri hedefler: bunlar, yerleşik olmayanların yurtiçi varlık alım satımlarına uygulanan kısıtlamalardır. Çıkış kontrolleri ise brüt çıkışları hedefler: bunlar, yerleşiklerin dış varlık satın alımlarına uygulanan kisitlamalardir.
} 
kredilerin vadesi, 2012 Haziran ayından itibaren kademeli olarak düşürülmüştür. Portföy hisse girişleri üzerindeki vergi 2011 yılının Aralık ayında, türev ürünler ve sabit getirili kıymetler üzerindeki vergi ise 2013 yılının Haziran ayında kaldırılmıştır. Aynı dönemde bankaların rezerv zorunlulukları da önemli ölçüde azaltılmışırır.

Brezilya'da özellikle sabit getirili menkul kıymetler üzerindeki vergilerin \%6'ya yükseltilmesinin ardından, portföy borç akımları azalmış, FDI girişleri ise önemli ölçüde artmıştır. 2011'de Brezilya'da dış borcun yaklaşık dörtte üçü bir yıldan kısa vadeliyken; vadesi beş yıla kadar olan dış borca \%6 vergi uygulandıktan sonra, vadeler beş yıl ve üzerine çıkmıştır (Chamon ve Garcia, 2016). Öyleyse Brazilya'da uygulanan sermaye kontrollerinin, toplam sermaye girişlerinin bileşimini FDI lehine değiştirmede ve dış borcun vadesini uzun vade lehine değiştirmede etkili olduğu söylenebilir.

Chamon ve Garcia (2016) sermaye kontrollerinin etkililiğini, yurtiçi ve yurtdışı dolar faiz oranı arasındaki farka (spread) bakarak değerlendirmektedir. Yazarlara göre, Brezilya'da 2002 yılından itibaren görece düşük seyreden bu fark, özellikle 2011 yılında kısa vadeli dış kredilere uygulanan vergilerden sonra artmıştır. Daha önceden yurtdışından kısa vadeli borçlanan Brezilya bankaları, bu dönemden itibaren yurtdışından uzun vadeli borçlanmaya başlamışlardır. Ardından türev araçlara vergi uygulanmasıyla birlikte, yabancıların yurtiçi türev ürün piyasalarında ara kazanç ticareti (carry trade) imkânları da kalmayınca, yabancıların toplam net pozisyonunda belirgin bir azalma olmuştur. Kısacası kontroller, yurtiçi varlıkları daha pahalı hale getirerek, Brezilya finans piyasasını uluslararası piyasalardan ayırmada kısmen etkili olmuştur. Bu süreçte Brezilya reali de önemli oranda değer kaybetmiştir. Chamon ve Garcia (2016), sermaye kontrollerinin döviz kuru üzerinde yarattı̆g 1 bu etkiyi regresyon tahminleri ile de kanıtlamaktadır. Öyleyse Brezilya'da Küresel Kriz sonrasında uygulanan sermaye kontrolleri, yerli paranın değer kazancını önlemede de etkili olmuştur.

Van der Lan vd. (2017), 2007:M1-2013:M12 dönemine ait aylık verileri kullanarak, Brezilya'da sermaye girişlerine uygulanan vergilerin etkilerini, tek değişkenli yapısal model aracılığıyla analiz etmektedir. Yazarlar, bu vergilerdeki değişmelerin portföy girişlerinde yapısal kırılma yarattığını; dolayısıyla sermaye girişleri üzerindeki vergilerin, bu girişleri azaltmada etkili olduğunu buluyorlar. Lambert vd. (2013) de, Brezilya'da uygulanan vergi artışlarının etkilerini incelemektedir. Çalışmada 2004:M4-2011:M6 dönemine ait aylık veriler kullanılarak regresyon tahminleri yapılıyor. Tahminler sonucunda, sabit getirili menkul kıymetler üzerindeki sermaye kontrolleri sıkılaştırıldığında, Brezilya'ya yönelik tahvil girişlerinin yavaşladığına dair kanıtlar bulunuyor. Ayrıca tahviller üzerindeki vergi artışının, Brezilya'ya hisse girişlerini ve yabancıların yurtiçindeki iştiraklerine verdikleri şirket içi kredi girişlerini artırdığını gösteren güçlü kanıtlar elde ediliyor. Bu sonuçlar vektör oto regresyon (VAR) tahminleriyle de destekleniyor. Bir finansal FDI olan şirket içi kredi girişlerindeki bu artış, yabancıların bu kredileri sermaye kontrollerinden kaçınmak için bir yöntem olarak kullandıkları biçiminde yorumlanıyor.

Forbes vd. (2016) ise, Brezilya'nın portföy girişlerine uyguladığı vergilerin uluslararası portföy dağılımı üzerindeki etkilerini incelemektedir. Panel regresyon sonuçlarına göre, Brezilya'da portföy tahvil girişleri üzerindeki vergilerin artması, uluslararası yatırımcıların Brezilya'ya tahsis ettikleri hisse ve tahvil fonlarının gelişen piyasalara dönük toplam portföyleri içindeki payını önemli ölçüde azaltıyor. Yani Brezilya'da tahvil girişleri üzerindeki vergiler artınca, uluslararası fon yöneticileri, Brezilya'ya yönelik tahvil yatırımlarının payını azaltmakla kalmıyorlar, aynı zamanda hisse senedi yatırımlarının payını da azaltıyorlar. Yazarlara göre bu sonuç, sermaye kontrollerinin sadece doğrudan vergi maliyeti yoluyla değil, aynı zamanda sinyal etkisi ile de sermaye akımlarını etkileyebileceğini gösteriyor. Bir başka deyişle, Brezilya'nın tahvil girişleri üzerindeki vergileri artırması, yatırımcılar tarafından devletin heterodoks politikaları uygulama isteğinin bir sinyali olarak algılanmıştır. Forbes vd. (2016), sermaye kontrollerinin böyle bir sinyal etkisine sahip olmasının, belli politika hedeflerine ulaşmada sermaye kontrollerinin etkililiğinin sorgulanmasına yol açabileceğini savunuyorlar. Buna göre, hükümetlerin sermaye kontrollerini kullanma gerekçelerinden biri de, sermaye girişlerinin bileşimini daha güvenli girişler lehine değiştirmektir. Ancak sermaye kontrollerinin sinyal etkisi yaratmasi; bu kontrollerin, yabancı sermayenin diğer biçimlerini etkilemeksizin belirli sermaye girişlerini hedeflemede başarılı olamayacağı anlamına gelebilir.

Brezilya'da Küresel Kriz sonrasında uygulanan sermaye kontrollerinin etkililiğini inceleyen çalışmaların bulgularını birlikte değerlendirdiğimizde çıkan sonuçları özetlemekte fayda vardır. Öncelikle, ele alınan dört çalışmada da, kontrollerin portföy borç girişlerini azalttığı kanıtlanıyor. Chamon ve Garcia (2016), sermaye kontrollerinin FDI girişlerini artırdığını gösteriyor. Lambert vd. (2013), bu kontrollerin FDI ve hisse girişlerini artırdığını; buna karşın Forbes vd. (2016) hisse girişlerini azalttığını buluyor.

Bruno ve Shin (2014), Güney Kore ekonomisinde 2010 sonrasında uygulanan sermaye kontrollerinin ve diğer makro ihtiyati politikaların etkilerini değerlendirmek amacıyla, sermaye akımlarının küresel finansal koşullara duyarlılığını ölçen bir yöntem geliştiriyor. Bunun için Güney Kore'nin de içinde olduğu 48 
ekonomiyi kapsayan bir örneklem kullanılarak, 1996:Q1-2012:Q1 dönemine dair bir panel çalışması yapılıyor. Çalışmada, Güney Kore dışındaki ülkeler karşılaştırma grubu olarak ele alınıyor. Öncelikle tüm örneklem dönemi boyunca, Kore'nin sermaye akımlarının küresel faktörlere olan duyarlılığının, diğer ülkelere kıyasla ne durumda olduğu tespit ediliyor. İkinci aşamada, diğer ülkelere kıyasla Güney Kore'nin küresel finansal koşullara duyarlılığının, Haziran 2010'da ihtiyati tedbirlerin uygulanmasından sonra değişip değişmediği araştırılıyor. Daha önce belirtildiği gibi, Güney Kore'nin makro ihtiyati politikaları hayata geçirdiği 2010-2013 dönemi, küresel likidite koşullarının gevşediği bir dönemdir. Küresel likidite koşullarının ölçütü olarak iki gösterge ele alınıyor. Bunlardan biri, küresel bankaların sınır ötesi faaliyetlerinin hacmi, diğeri ise VIX endeksidir (Chicago Board Options Exchange Volatility Index). Bu iki göstergedeki değişmelerin, Güney Kore'de ve diğer ülkelerde sermaye girişleri üzerinde yarattıkları etkilere bakılarak, ülkelerin küresel koşullara duyarlılıkları ölçülüyor. Güney Kore'nin tarihsel olarak bu iki göstergeye, diğer ülkelerden daha duyarlı olduğu belirleniyor. Haziran 2010'dan sonra ise, Güney Kore dışındaki ülkelerin söz konusu iki göstergeye daha duyarlı hale geldikleri, buna karşın Güney Kore'nin daha az duyarlı hale geldiği bulunuyor. Dolayısıyla Güney Kore'de sermaye akımlarının küresel koşullara duyarlılığının, ihtiyati politikaların uygulanmasından sonra azaldığı bulgusu elde ediliyor.

Küresel Kriz sonrasında sermaye kontrollerinin etkilerini inceleyen çok ülkeli çalışmalardan biri, Ahmed ve Zlate (2014) tarafindan yapılmıştır. Söz konusu çalışmada, 12 gelişmekte olan ülkenin 2009:Q3-2013:Q2 dönemine ait verileri kullanılarak, bu ülkelerde uygulanan sermaye kontrollerinin, net ve brüt sermaye girişleri üzerinde yarattığı etkiler incelenmektedir. Ele alınan ülkelerden beş tanesi (Brezilya, Endonezya, Kore, Tayvan ve Tayland) Küresel Kriz sonrasında sermaye kontrolü uygulamış olanlardır. Makalede sermaye kontrollerine ilişkin iki çeşit değişken oluşturuluyor. Birincisi, belirli bir dönemde uygulanan sermaye kontrolü tedbirlerinin birikmiş sayısı; ikincisi ise, belirli bir dönemde uygulanmaya başlanan yeni sermaye kontrolü tedbirlerinin sayısıdır. Basit en küçük kareler yöntemi (OLS) kullanılarak yapılan tahmin sonuçlarına göre; birikmiş sermaye kontrolü tedbirlerinin sayısı, net (ve brüt) toplam ve net (ve brüt) portföy yatırımları üzerinde negatif ve anlamlı etki yaratmaktadır. Yeni uygulanan sermaye kontrolü tedbirlerinin sayısı ise, net sermaye girişleri ve brüt portföy girişleri üzerinde gecikmeli negatif ve anlamlı etki yaratmaktadır. Böylece Küresel Kriz sonrasında bazı gelişmekte olan ülkelerde uygulanan sermaye kontrollerinin, sermaye girişlerini azaltıcı etkilere sahip olduğu sonucuna ulaş1lyyor.

Pasricha vd. (2018), sermaye kontrollerinin net akımlardan çok brüt akımları etkilediğini savunmaktadır. Adı geçen çalışmada, 16 gelişmekte olan ülkenin 2001:Q1-2012:Q4 dönemine ait verileri kullanılarak panel yapısal VAR analizi yapılıyor. Ulaşılan sonuçlara göre, giriş kontrollerindeki artış; hem brüt sermaye girişlerinde hem de brüt sermaye çıkışlarında azalmaya yol açarken, net sermaye girişleri üzerinde sınırlı etki yaratıyor. Ayrıca giriş kontrollerindeki sıkılaşma, döviz kurunun oynaklığı ile yurtiçi ve yurtdışı faiz farkını artırıyor. Böylece ele alınan dönemde sermaye giriş kontrollerindeki artışların, döviz kuru istikrarını azalttığı ve parasal bağımsızlığı artırdığı gösteriliyor.

Sermaye kontrollerinin parasal bağımsızlık üzerindeki etkilerini araştıran bir başka çalışma olan You vd. (2014), 88 ülkenin 1995-2010 dönemine ait verilerini kullanmaktadır. Söz konusu çalışmada, yurtiçi ve yurtdışı faiz oranları arasındaki korelasyon ile ölçülen bir para politikası bağımsızlık endeksi oluşturuluyor. GMM tahmin sonuçlarına göre, sermaye kontrolleri parasal bağımsızlığı artırıyor. Bulgular, sermaye kontrollerinin parasal bağımsızlık üzerindeki etkililiğinin, kontrol uygulanan bileşenler yanında akımların yönüne de bağlı olduğunu gösteriyor. Buna göre, hisse senedi ve doğrudan yatırımlar üzerindeki kontrollerin, tahvil ve finansal krediler üzerindeki kontrollerden daha etkili olduğu tespit ediliyor. Ayrıca giriş kontrollerinin, çıkış kontrollerinden daha etkili olduğu bulunuyor. Diğer taraftan döviz kuru rejimi de, sermaye kontrollerinin parasal bağımsızlık üzerindeki etkililiğini belirliyor. Buna göre sabit döviz kuru rejimi, para politikası özerkliğini azaltıyor.

Ghosh vd. (2014), sermayenin kaynağı olan ülkelerdeki çıkış kontrolleriyle sermayenin alıcısı olan ülkelerdeki giriş kontrollerinin birlikte uygulanması suretiyle, sermaye akımlarının düzenlenip düzenlenemeyeceğini incelemektedir. $\mathrm{Bu}$ amaçla, 1995-2012 yılları arasında 31 kaynak ülkeden 76 alıc1 ülkeye iki taraflı (giriş ve çıkış) sınır ötesi banka akımlarına ilişkin veriler kullanılıyor. Dolayısıyla kaynak ülkelerdeki çıkış kontrolleri ile alıcı ülkelerdeki giriş kontrollerine ilişkin veriler birleştiriliyor ve bu kontrollerin bankacılık akımları üzerindeki etkileri araştırılıyor. OLS tahminlerine göre, kaynak ülkelerde tahvil, hisse senedi, FDI ve finansal kredi çıkışları üzerindeki kontrollerin artması, kaynak ülkelerden bankacılık çıkışlarını anlamlı şekilde azaltıyor. Diğer taraftan alıcı ülkelerde toplam sermaye girişleri ve tahvil girişleri üzerindeki kontrollerin artması, alıcı ülkelerde bankacılık girişlerini azaltıyor. Üstelik hem alıcı ülkelerdeki giriş hem de kaynak ülkelerdeki çıkış kontrolleri birlikte regresyona dâhil edildiklerinde de bu etkilerin anlamlılığı devam ediyor. Dolayısıyla giriş ve çıkış kontrollerinin birlikte anlamlı biçimde etkili 
olması, sermaye kontrollerinin hem kaynak hem de alıcı ülkelerde birlikte uygulanabileceğini gösteriyor. Sermaye kontrollerinin her iki uçta birlikte uygulanması durumunda, akımlarda daha büyük azalma olacağı ve sınır ötesi banka akımlarının hacminin önemli ölçüde etkilenebileceği kanıtlanıyor. Yazarlara göre bu bulgular, potansiyel olarak istikrar bozucu akımları daha iyi yönetmek için alıcı ülkelerin kendi aralarında olduğu kadar, kaynak ülkeler ile alıcı ülkeler arasındaki politika koordinasyonunun da faydalı olabileceğini ortaya koymaktadır.

Dell'Erba ve Reinhardt (2015), brüt sermaye girişlerinde geniş çaplı artışların olduğu dönemlerde, giriş kontrollerinin bankacılık borç akımları ve finansal FDI akımları üzerindeki etkilerini incelemektedir. 56 gelişmekte olan ülkenin 1985-2010 dönemine ait verileri kullanılarak yapılan Logit model tahminlerine göre; kısa vadeli borç girişlerine getirilen kontroller, bankacılık borç girişlerinde artış olasılığını azaltırken, finansal FDI girişlerinde artış olasılığını artırıyor. Buna göre borç girişleri üzerindeki kontroller, sermaye girişlerinin bileşimini, bankacılık girişlerinden finansal FDI girişlerine kaydırmaktadır. Öyleyse giriş kontrolleri karşısında finansal FDI, uluslararası yatırımcılar tarafından borç girişlerine yakın ikame olarak kullanılabilmektedir. Yazarlara göre; finansal FDI, diğer FDI türlerine göre daha az güvenli ve daha oynak olduğu ölçüde, sermaye akımlarının bileşiminin finansal FDI lehine değişmesinin olumlu olduğu görüşüne ihtiyatlı yaklaşmak gerekir.

Bruno vd. (2017), sermaye kontrollerinin ve diğer makro ihtiyati politikaların bankacılık ve tahvil girişleri üzerindeki etkilerini değerlendirirken, 12 Asya-Pasifik ekonomisinin 2004-2013 yılları arasındaki verilerini kullanmaktadır. Adı geçen çalışmanın bulgularına göre, bankacılık kesimi ve tahvil piyasası giriş kontrolleri, sırasıyla bankacılık kesimi ve tahvil piyasası girişlerinde yavaşlamaya eşlik ediyor. Yazarlar, bankacılık girişlerinin 2007 öncesinde, tahvil girişlerinin ise 2009 sonrasında hızlı artış yaşadığını göz önünde bulundurarak analiz yapıyorlar. Üç aylık veriler kullanılarak yapılan panel regresyon ve dinamik GMM tahminleriyle, bankacılık kesimi giriş kontrollerindeki artışın, 2007 yılından önce tahvil girişlerinde artışa eşlik ettiği; tahvil piyasası giriş kontrollerindeki artışın ise, 2009 yılından sonra bankacılık girişlerinde artışa eşlik ettiği tespit ediliyor. Buna göre, bir kesime yönelik giriş kontrollerindeki artış, bir başka kesime yönelik girişlerin artmasına yol açıyor. Buradan, yatırımcıların kontrollerden kaçınmak için, bankacılık girişleri ile tahvil girişlerini birbirinin yerine kullanabildikleri anlaşılıyor. Ayrıca bankacılık kesimi ve tahvil piyasası kontrolleri; daha sıkı sermaye kontrollerine sahip olan ülkelerde, bankacılık ve tahvil girişlerinin hızlı büyüdüğü dönemlerde etkili olurken, daha gevşek sermaye kontrolüne sahip ülkelerde, bu girişlerinin yavaş büyüdügü dönemlerde etkili oluyor. Öyleyse sermaye kontrolleri, sermaye hesabının açıklık derecesine bağlı olarak heterojen sonuçlar yaratabilmektedir. Bir başka deyişle giriş kontrollerinin etkililiği, ülkelerin ne ölçüde sıkı kontrol uyguladıklarına da bağlıdır.

Sermaye kontrollerinin derecesi, ekonomik şokların çeşitli finansal ve makroekonomik değişkenler üzerindeki etkilerinin de farklılaşmasına yol açabilir. Zeev (2017), küresel kredi arz şokları karşısında sermaye kontrollerinin şok emici kapasitesini incelemektedir. Sözü edilen çalışmada 33 gelişmekte olan ülkenin 1995 2014 dönemine ait verileri kullanılarak etki-tepki analizi yapılıyor. Analiz, küresel bir kredi arz şokuna tepki olarak, s1kı kontrollerin uygulandığı durumda -kontrollerin gevşek olduğu duruma göre- çıtının çok daha az düştüğünü gösteriyor. Öyleyse toplam sermaye girişleri üzerindeki kontroller, arz şokunun çıktı üzerindeki etkilerini hafifletiyor ve makroekonomik oynaklığı azaltıyor. Buna göre sermaye girişi kontrollerinin şok emici kapasiteye sahip olduğu söylenebilir. Buna karşın sermaye çıkış kontrollerinin, çıktının arz şokları karşısındaki duyarlılığını azaltmadığı; dolayısıyla çıkış kontrollerinin şok emici kapasiteye sahip olmadığı gösteriliyor. Ayrıca, gevşek kontrol uygulayan ülkelerde arz şokuna tepki olarak ülke risk priminin çok daha fazla arttığı ve borç/GDP oranının çok daha fazla düştüğü sonucuna ulaşıyor. Yazar, bu sonuçlar 1şığında giriş kontrollerinin makroekonomik istikrarı artırmada etkili bir politika aracı olduğunu savunuyor.

Sermaye kontrollerinin makroekonomik istikrar üzerindeki etkileri, Erten ve Ocampo (2017) çalışmasında da ele alınmaktadır. Söz konusu makalede, 51 gelişmekte olan ekonominin 1995-2011 dönemine ait verileri kullanılarak panel regresyon tahminleri yapılıyor. Ulaşılan bulgular, hem giriş hem de çıkış kontrollerinin, döviz piyasası baskısını ve yerli paranın reel değer kazancını azalttığını gösteriyor. Ayrıca Küresel Kriz sırasında daha sıkı sermaye kontrolü uygulayan ülkelerde büyüme oranlarındaki düşüşlerin daha az olduğu kanıtlanırken; sermaye kontrollerinin ülkelerin krizden daha çabuk çıkmalarını sağlayabileceği ifade ediliyor. Diğer taraftan Kriz sonrası dönemde giriş kontrolü uygulayan ülkelerde ekonomideki isınmanın daha az olduğu ispatlanırken; sermaye kontrollerinin ülkelerin dış finansmanın yarattı̆̆ı genişleme daralma çevrimlerinden daha az etkilenmelerini sağlayacağı belirtiliyor. Yazarlara göre bu sonuçlar, sermaye kontrollerinin makroekonomik istikrarın sağlanmasına yardımcı olabileceğini gösteriyor.

Aizenman ve Binici (2016), dinamik panel regresyon analizi kullanarak, sermaye kontrollerinin döviz piyasası baskısı üzerindeki rolünü incelemektedir. Çalışmada 22 OECD ülkesi ve 28 gelişen piyasa 
ekonomisinin 2000:Q1-2014:Q3 dönemine ait verileri kullanılıyor. Bütün örneklem kullanılarak yapılan tahminler sonucunda, hem giriş hem de çıkış kontrollerinin anlamlı biçimde döviz piyasası baskısını azalttığı bulunuyor. Örneklem OECD ülkeleri ve gelişen piyasa ekonomileri diye ikiye ayrıldığında, kontrollerin OECD ülkelerinde anlamlılığ devam ederken, gelişen piyasa ekonomilerinde ne giriş ne de çıkış kontrollerinin döviz piyasası baskısı üzerinde anlamlı bir etkisi olmadığı görülüyor. Buna göre sermaye kontrollerinin gelişmiş ülkelerde, gelişmekte olan ülkelere göre daha etkili olduğu vurgulanıyor. Sonuç olarak, sermaye kontrollerinin döviz baskılarını azaltmada etkili olduğu; fakat bu etkinin derecesinin, ülkenin kontrolleri uygulama kabiliyetini yansıtan kurumsal kalitesine bağlı olduğu belirtiliyor.

Li ve Rajan (2015) çalışmasında ise, panel regresyon yöntemiyle sermaye kontrollerinin, brüt sermaye girişlerinin (doğrudan yatırım, portföy yatırımları ve hisse senedi yatırımları) oynaklığını etkileyip etkilemediği araştırılmaktadır. Makalede 37 gelişen piyasa ekonomisinin 1995-2011 dönemine ait verileri kullanılarak; belirli tipteki sermaye akımlarına konulan kontrollerin, hem karşılık gelen kendi girişleri hem de diğer bileşenler üzerinde yarattığı etkiler inceleniyor. Ulaşılan bulgulara göre, FDI çıkışlarına konulan kontroller, FDI girişlerinin oynaklığını düşürüyor. Hisse senedi çıkışlarına uygulanan kontroller, hisse senedi girişlerinin oynaklığını azaltıyor. Portföy çıkışlarına konulan kontroller ise, FDI girişlerinin oynaklığını azaltıyor. Diğer taraftan hisse girişlerine, portföy girişlerine veya FDI girişlerine konulan kontroller, herhangi bir sermaye girişi bileşeninin oynaklığı üzerinde anlamlı bir etki yaratmıyor. Buna göre, çıkış kontrollerinin giriş kontrollerinden daha etkili olduğu sonucuna ulaşılıyor.

Panel regresyon yöntemini kullanan bir başka çalışma olan Zhang ve Zoli (2016) makalesinde, 2000-2013 dönemine ait 46 ülkenin verileri ile analiz yapılmaktadır. Adı geçen makalede ele alınan ülkelerden 13 tanesi Asya bölgesinden seçilirken, sermaye kontrollerinin finansal kırılganlık ve portföy girişleri üzerindeki etkileri araştırılıyor. Analiz sonucunda sermaye kontrollerinin bütün örneklem için kredi büyümesini, konut fiyat artışını ve portföy hisse girişlerini yavaşlattığı; ancak bu sonuçların Asya ekonomileri için geçerli olmadığı sonucuna ulaşllıyor. Diğer taraftan, sermaye kontrollerinin ve makro ihtiyati tedbirlerin, portföy borç senedi girişleri üzerinde anlamlı bir etki yaratmadığı gösteriliyor.

Forbes vd. (2015), sermaye kontrollerinin finansal kırılganlık, döviz kurları ve sermaye akımları üzerindeki etkililiğini incelerken, eğilim puanı eşleştirme (propensity-score matching) yöntemini kullanmaktadır. Yazarlar, sermaye kontrollerini değiştiren ülkelerin genellikle belirli ortak özelliklere sahip olduklarını ve belirli değişkenlere tepki verdiklerini düşünüyorlar. Bu varsayım çerçevesinde, gözlemlenebilir değişkenlere dayanarak her bir ülkenin belirli bir sermaye kontrolünü benimseme olasılığının eğilim puanları tahmin ediliyor. Ardından, bu eğilim puanları sermaye kontrolü uygulayan ülkeler ile kontrol uygulamayan ülkeleri eşleştirmek için kullanılıyor. Bu sayede benzer sermaye kontrolü uygulama kabiliyetine sahip olan ülkelerde ortaya çıkan sonuçlar karşılaştırılıyor. Söz konusu çalışmada 60 ülkenin 2009-2011 dönemine ait haftalık verileri kullanılarak analiz yapılıyor. Makalede, sermaye kontrollerinin döviz kurlarını ve net sermaye akımlarını etkilediğine dair güçlü bir kanıt bulunamıyor. Sermaye kontrollerindeki değişmeler, diğer makroekonomik değişkenleri ve finansal piyasa oynaklıklarını (hisse senedi getirileri, enflasyon, döviz kuru oynaklığı ve faiz oranı farklılıkları gibi) da önemli ölçüde etkilemiyor. Bunun tek istisnası var: sermaye çıkış kontrollerinin kaldırılması, yerli parada önemli bir değer kaybı yaratıyor. Bu sonuçlar çerçevesinde yazarlar, yerli paranın değer kazancını önlemek için, giriş kontrollerinin artırılması yerine çıkış kontrollerinin gevşetilmesi gerektiğini savunuyorlar. Diğer taraftan, sermaye girişlerine dönük artan kontrollerin, kredilerdeki büyümeyi azalttığı ispatlanıyor. Dolayısıyla sermaye kontrollerinin en güçlü etkisi, finansal kırılganlığı azaltma biçiminde ortaya çıkıyor.

Jongwanich (2019) çalışması, 2000-2015 dönemi için on Asya ekonomisinin verilerini kullanarak, sermaye kontrollerinin sermaye akımları üzerindeki etkilerini GMM tahminleriyle incelemektedir. Çalışmada hem girişler hem de çıkışlar üzerindeki kontroller dikkate alınıyor ve sermaye akımlarının dört bileşeni (doğrudan yatırım, hisse senedi, borç senedi ve diğer yatırımlar) ayrı ayrı inceleniyor. Sonuçlar, doğrudan yatırım ve hisse senedi girişleri üzerindeki kısıtlamaların, bu akımları azaltmada etkili olduğunu; ancak borç senedi ve diğer yatırım girişleri üzerindeki kontrollerin etkili olmadığını gösteriyor. Çıkış tarafında ise, kontrollerin yalnızca diğer yatırımlar bileşeni için etkili olduğu bulunuyor. Dolayısıyla giriş kontrollerinin, çıkış kontrollerinden daha etkili olduğu sonucu çıkarılıyor. Bununla birlikte, belirli bir bileşen üzerindeki kısıtlamaların, diğer bileşenleri etkileyebildiği ispatlarken; bu kısıtlamaların sinyal etkisine sahip olabileceği gösteriliyor. Buna göre doğrudan yatırım girişleri üzerindeki kontrollerin, hisse senedi girişlerini azalttığı ve bunun tersinin de geçerli olduğu tespit ediliyor. Borç senedi girişlerindeki kontrollerin de, hisse senedi girişlerini azalttığı belirleniyor. 
Tablo 1. Küresel Kriz Sonrasında Sermaye Kontrollerinin Etkililiğini Araştıran Ampirik Çalışmalar

\begin{tabular}{|c|c|c|c|}
\hline Makale & $\begin{array}{l}\text { Dönem/Yöntem/ } \\
\text { Sermaye kontrol } \\
\text { endeksi }\end{array}$ & Ülkeler & $\begin{array}{l}\text { Bulgular } \\
\text { Sermaye giriş kontrolleri... }\end{array}$ \\
\hline $\begin{array}{l}\text { Chamon ve } \\
\text { Garcia } \\
(2016)\end{array}$ & $\begin{array}{l}\text { 2009-2012 günlük/ } \\
\text { OLS/Yazar(lar)1n } \\
\text { endeksi }\end{array}$ & Brezilya & $\begin{array}{l}\text { yerli para değer kazancını önlüyor; dış borcun vadesini } \\
\text { uzatıyor; sermaye girişlerinin bileşimini değiştiriyor. }\end{array}$ \\
\hline $\begin{array}{l}\text { Van der Lan } \\
\text { vd. (2017) }\end{array}$ & $\begin{array}{l}\text { 2007:M1-2013:M12/ } \\
\text { Tek değ. yapısal } \\
\text { model/Yazar(lar)ın } \\
\text { endeksi }\end{array}$ & Brezilya & $\begin{array}{l}\text { portföy yatırım girişlerinde yapısal kırılma yaratarak, } \\
\text { sermaye girişlerini azaltıyor. }\end{array}$ \\
\hline $\begin{array}{l}\text { Lambert vd. } \\
(2013)\end{array}$ & $\begin{array}{l}\text { 2004:M4-2011:M6/ } \\
\text { Regresyon ve VAR/ } \\
\text { Yazar(lar)1n endeksi }\end{array}$ & Brezilya & $\begin{array}{l}\text { tahvil girişlerini yavaşlatıyor; hisse senedi ve finansal FDI } \\
\text { girişlerini artırıyor. }\end{array}$ \\
\hline $\begin{array}{l}\text { Forbes vd. } \\
(2016)\end{array}$ & $\begin{array}{l}\text { 2005:M1-2013:M12/ } \\
\text { Resresyon/ } \\
\text { Yazar(lar)1n endeksi }\end{array}$ & Brezilya & tahvil girişlerini ve hisse girişlerini yavaşlatıyor. \\
\hline $\begin{array}{l}\text { Bruno ve } \\
\text { Shin (2014) }\end{array}$ & $\begin{array}{l}\text { 1996:Q1-2012:Q1/ } \\
\text { Panel regresyon/ } \\
\text { Yazar(lar)1n endeksi }\end{array}$ & Güney Kore & $\begin{array}{l}\text { sermaye akımlarının küresel koşullara duyarlılığını } \\
\text { azaltıyor. }\end{array}$ \\
\hline $\begin{array}{l}\text { Ahmed ve } \\
\text { Zlate (2014) }\end{array}$ & $\begin{array}{l}\text { 2009:Q3-2013:Q2/ } \\
\text { OLS/ } \\
\text { Yazar(lar)1n endeksi }\end{array}$ & $\begin{array}{l}12 \text { gelişen } \\
\text { piyasa } \\
\text { ekonomisi }\end{array}$ & $\begin{array}{l}\text { net (ve brüt) toplam sermaye girişlerini ve portföy girişlerini } \\
\text { azaltıyor. }\end{array}$ \\
\hline $\begin{array}{l}\text { Pasricha vd. } \\
(2018)\end{array}$ & $\begin{array}{l}\text { 2001:Q1-2012:Q4/ } \\
\text { panel yap1sal VAR/ } \\
\text { Fernandez vd. (2015) }\end{array}$ & $\begin{array}{l}16 \text { gelişen } \\
\text { piyasa } \\
\text { ekonomisi }\end{array}$ & $\begin{array}{l}\text { brüt toplam sermaye girişlerini (ve çıkışlarını) azaltıyor, net } \\
\text { girişleri etkilemiyor; döviz kuru oynaklığını artırıyor; para } \\
\text { politikası özerkliğini artırıyor. }\end{array}$ \\
\hline $\begin{array}{l}\text { You vd. } \\
(2014)\end{array}$ & $\begin{array}{l}\text { 1995-2010/ } \\
\text { GMM/ } \\
\text { AREAER }\end{array}$ & 88 ülke & $\begin{array}{l}\text { para politikası özerkliğini artırıyor; (hisse ve FDI) } \\
\text { kontrolleri, (tahvil ve finansal kredi) kontrollerinden daha } \\
\text { etkilidir. } \\
\text { Giriş kontrolleri, çıkış kontrollerinden daha etkilidir. }\end{array}$ \\
\hline $\begin{array}{l}\text { Ghosh vd. } \\
(2014)\end{array}$ & $\begin{array}{l}\text { 1995-2012/ } \\
\text { OLS/ } \\
\text { AREAER }\end{array}$ & $\begin{array}{l}31 \text { kaynak } \\
\text { ve } \\
76 \text { alıcı ülke }\end{array}$ & $\begin{array}{l}\text { (toplam ve tahvil) kontrolleri, bankacılık girişlerini } \\
\text { azaltıyor. }\end{array}$ \\
\hline $\begin{array}{l}\text { Dell'Erba ve } \\
\text { Reinhardt } \\
(2015)\end{array}$ & $\begin{array}{l}\text { 1985-2010/ } \\
\text { Koşula bağlı logit/ } \\
\text { Fernandez vd. (2015) }\end{array}$ & $\begin{array}{l}56 \text { gelişen } \\
\text { piyasa } \\
\text { ekonomisi }\end{array}$ & $\begin{array}{l}\text { (banka borç) kontrolleri, bankacılık girişlerini azaltıyor; } \\
\text { finansal FDI girişlerini artırıyor; sermaye girişlerinin } \\
\text { bileşimini değiştiriyor. }\end{array}$ \\
\hline $\begin{array}{l}\text { Bruno vd. } \\
(2017)\end{array}$ & $\begin{array}{l}\text { 2004-2013/ } \\
\text { Dinamik GMM/ } \\
\text { AREAER }\end{array}$ & $\begin{array}{l}12 \text { Asya- } \\
\text { Pasifik } \\
\text { ülkesi }\end{array}$ & $\begin{array}{l}\text { (tahvil) ve (banka) kontrolleri, sırasıyla tahvil ve banka } \\
\text { girişlerini yavaşlatıyor; (tahvil) kontrolleri, } 2009 \text { sonrasında } \\
\text { banka girişlerini artırıyor; (banka) kontrolleri, } 2007 \\
\text { öncesinde tahvil girişlerini artırıyor. }\end{array}$ \\
\hline Zeev (2017) & $\begin{array}{l}\text { 1995-2014/ } \\
\text { Etki-tepki analizi/ } \\
\text { Fernandez vd. (2015) }\end{array}$ & $\begin{array}{l}33 \text { gelişen } \\
\text { piyasa } \\
\text { ekonomisi }\end{array}$ & $\begin{array}{l}\text { arz şokları karşısında, çıktıdaki dalgalanmaları ve } \\
\text { makroekonomik oynaklığı azaltıyor. } \\
\text { Çıkış kontrolleri ise şok emici etkiye sahip değildir. }\end{array}$ \\
\hline $\begin{array}{l}\text { Erten ve } \\
\text { Ocampo } \\
(2017)\end{array}$ & $\begin{array}{l}\text { 1995-2011/ } \\
\text { Panel regresyon/ } \\
\text { AREAER }\end{array}$ & $\begin{array}{l}51 \text { gelişen } \\
\text { piyasa } \\
\text { ekonomisi }\end{array}$ & $\begin{array}{l}\text { döviz piyasası baskısını azaltıyor; yerli paranın değer } \\
\text { kazancını azaltıyor; aşırı ısınmayı önlüyor. } \\
\text { Çıkış kontrolleri de, döviz piyasası baskısını ve yerli } \\
\text { paranın reel değer kazancını azaltıyor. }\end{array}$ \\
\hline $\begin{array}{l}\text { Aizenman } \\
\text { ve Binici } \\
(2016)\end{array}$ & $\begin{array}{l}\text { 2000:Q1-2014:Q3/ } \\
\text { Dinamik panel } \\
\text { regresyon/ } \\
\text { Fernandez vd. (2015) }\end{array}$ & $\begin{array}{l}22 \text { OECD ve } \\
28 \text { gelişen } \\
\text { piyasa } \\
\text { ekonomisi }\end{array}$ & $\begin{array}{l}\text { OECD ülkelerinde döviz piyasası baskısını azaltıyor } \\
\text { (gelişen piyasalarda anlamlı değil). } \\
\text { Çıkış kontrolleri de, OECD ülkelerinde döviz piyasası } \\
\text { baskısını azaltıyor. }\end{array}$ \\
\hline $\begin{array}{l}\text { Li ve Rajan } \\
(2015)\end{array}$ & $\begin{array}{l}\text { 1995-2011/ } \\
\text { Panel regresyon/ } \\
\text { Fernandez vd. (2015) }\end{array}$ & $\begin{array}{l}37 \text { gelişen } \\
\text { piyasa } \\
\text { ekonomisi }\end{array}$ & $\begin{array}{l}\text { (hisse, portföy borç ve FDI) kontrolleri, sermaye girişlerinin } \\
\text { oynaklığını etkilemiyor. } \\
\text { Çıkış kontrolleri ise, sermaye girişlerinin oynaklığını } \\
\text { azaltıyor. }\end{array}$ \\
\hline $\begin{array}{l}\text { Zhang ve } \\
\text { Zoli (2016) }\end{array}$ & $\begin{array}{l}2000-2013 / \\
\text { Panel regresyon/ } \\
\text { Yazar(lar)1n endeksi }\end{array}$ & $\begin{array}{l}46 \\
\text { gelişmekte } \\
\text { olan ülke }\end{array}$ & $\begin{array}{l}\text { banka kredi büyümesini, konut fiyat artışını ve portföy hisse } \\
\text { girişlerini yavaşlatıyor; portföy borç girişlerini etkilemiyor. }\end{array}$ \\
\hline
\end{tabular}




\begin{tabular}{|l|l|l|l|}
\hline $\begin{array}{l}\text { Forbes vd. } \\
(2015)\end{array}$ & $\begin{array}{l}\text { 2009:w1-2011:w52/ } \\
\text { Eğilim puanı } \\
\text { eşleştirme/ } \\
\text { AREAER }\end{array}$ & 60 ülke & $\begin{array}{l}\text { banka kredi büyümesini yavaşlatıyor; döviz kuru ve net } \\
\text { sermaye akımlarını etkilemiyor. } \\
\text { Çıkış kontrollerinin kaldırılması, yerli paranın değer } \\
\text { kazancını önlüyor. }\end{array}$ \\
\hline $\begin{array}{l}\text { Jongwanich } \\
(2019)\end{array}$ & $\begin{array}{l}\text { 2000-2015/ } \\
\text { GMM/ } \\
\text { Fernandez vd. (2015) }\end{array}$ & $\begin{array}{l}\text { 10 Asya } \\
\text { ülkesi } \\
\text { ancaks (borç senedi ve diğer yatırım) kontrolleri etkili } \\
\text { değildir; (FDI ve borç) kontrolleri, hisse girişlerini } \\
\text { azaltıyor; (hisse) kontrolleri, FDI girişlerini yavaşlatıyor. } \\
\text { Giriş kontrolleri, çı1kş kontrollerinden daha etkilidir. }\end{array}$ \\
\hline
\end{tabular}

Kaynak: Yazar tarafindan oluşturulmuştur.

Tablo 1'de Küresel Kriz sonrasında sermaye kontrollerinin etkililiğini araştıran çalışmaların sonuçları özetlenmektedir. Kriz öncesi literatürde olduğu gibi, birçok çalışmada giriş kontrollerinin sermaye girişlerinin bileşimini değiştirmede ve para politikasındaki otonomiyi artırmada etkili olduğu ispatlanmaktadır. Ayrıca sermaye kontrollerinin makroekonomik ve finansal kırılganlıkları azalttı̆̆ını kanıtlayan çalışmalar da göze çarpmaktadır. Diğer taraftan sermaye kontrollerinin, toplam sermaye girişlerini azaltabileceğini ve döviz kuru baskısını hafifletebileceğini gösteren çalışmaların payının, Kriz öncesi literatüre göre daha yüksek olduğu söylenebilir. Bu sonuçlar, sermaye kontrollerinin belirli hedeflere ulaşmak için etkili bir politika aracı olarak kullanılabileceğini göstermektedir. Ancak sermaye girişlerinin belirli bileşenlerine dönük kontrollerin, diğer bileşenler üzerinde negatif ya da pozitif yönlü etkiler yaratabileceğine dair bulgular; kontrollerin daha güvenli yatırımlar lehine sonuç doğuracağı öngörüsünü tartışmalı hale getirmektedir. Forbes vd. (2016) ile Jongwanich (2019) çalışmalarında gösterildiği gibi, eğer sermaye kontrolleri sinyal etkisine sahipse; girişlerin belirli bir bileşenine dönük kontrollerdeki sıkılaşma, diğer bileşenlerin girişlerini azaltacak ve bu da kontrollerin diğer bileşenleri etkilemeksizin belirli bileşenleri hedeflemesini güçleştirecektir. Ayrıca Lambert vd. (2013), Dell'Erba \& Reinhardt (2015) ve Bruno vd. (2007) çalışmalarında belirtildiği gibi, eğer uluslararası yatırımcılar kontroller karşısında bazı bileşenleri ikame edebiliyorlarsa; bu durum yatırımcıların kontrollerden kaçınmalarını kolaylaştıracak ve sermaye kontrollerinden beklenen etkilerin ortaya çıkmasını zorlaştıracaktır. Diğer taraftan sermaye kontrollerinin etkilerinin, ülkelerin kurumsal kalitelerine (Aizenman ve Binici, 2016) ve kontrollerin ne derece sıkı uygulandığına (Zeev, 2017) bağlı olduğu yönündeki bulgular da, kontrollerin etkililiğine ilişkin farklı görüşlere yol açabilmektedir.

\subsection{Sermaye Kontrolleri Yayılma Etkileri Yaratıyor mu?}

Sermaye kontrollerinin, bunları uygulayan ülke ekonomisinde yaratacağı sonuçlar yanında, diğer ülkeler üzerinde ortaya çıkaracağı yayılma etkileri de önemlidir. Özellikle son yıllarda yeni teorik literatürün daha çok ön plana çıkardığı ve Küresel Kriz sonrasında daha fazla kullanılmaya başlanan (Pasricha, 2012) sermaye girişleri üzerindeki kontroller, üç tür yayılma etkisi yaratabilir. Birincisi, bir ülkede kontrollerin benimsenmesi, benzer özelliklere sahip olan ve kontrol uygulamayan başka ülkelere daha fazla sermaye girişine yol açabilir. Uluslararası sermaye akımlarının esas olarak iten faktörler tarafından yönlendirildiği bir ortamda, bu fonların kontrole tabi olmayacakları ülkelere yöneleceğini söyleyebiliriz. Bu etkiye ilişkin endişelerin kaynağı, bir ülkede makroekonomik ve finansal riskleri düşüreceği beklentisiyle hayata geçirilen sermaye kontrollerinin, başka ülkelerde benzer riskleri artırabileceği hususudur. İkincisi, bir ülkede yerli parayı sürekli olarak düşük değerli tutan sermaye kontrolleri, uluslararası ticarette ülkelerin nispi fiyat-rekabet gücünü etkilediği sürece dışsallıklar üretecektir. Bir ülkenin karşılaştırmalı üstünlük elde etmek için kontrolleri uygulaması, diğer ülkelerin misilleme yapmasıyla sonuçlanabilir ve bu da küresel düzeyde para savaşlarını başlatabilir. Komşuyu yoksullaştıran böyle bir para savaşının da, küresel refahı azaltacağını tahmin etmek güç değildir. Üçüncüsü, sermaye hareketliliğine getirilen kısıtlamalar, kaynakların küresel düzeyde dağılımını çarpıtabilir. Sermayenin optimal tahsisini engelleyen bu etki de, daha düşük küresel ekonomik büyüme ile sonuçlanabilir. Kısacası, bazı ülkelerde yürürlüğe konulan sermaye kontrolleri, diğer ülkelerde olumsuz dışsallıklar yaratarak küresel refahın düşmesine neden olabilir. Bu yüzden sermaye kontrollerine ilişkin ampirik literatürde, yalnızca kontrolleri uygulayan ülke üzerindeki etkiler değil, aynı zamanda diğer ülkelerde ortaya çıkan yayılma etkileri ve dışsallıklar da araştırılmaktadır.

Lambert vd. (2013), Brezilya'da 2010 yılında uygulamaya konulan portföy girişleri üzerindeki verginin, diğer Latin Amerika ekonomilerine yönelik sermaye akımlarını nasıl etkilediğini araştırmaktadır. VAR analizinin sonuçları, Brezilya'da tahvil girişlerine dönük vergi artışının, diğer Latin Amerika ülkelerine (Meksika, Arjantin, Şili, Kolombiya ve Peru) yönelik tahvil ve/veya hisse senedi girişlerini önemli ölçüde artırdığını kanıtlıyor. Dolayısıyla, Brezilya'da uygulanan giriş kontrollerinin, komşuları üzerinde olumsuz yayılma etkileri yarattığı ispatlanıyor. 
Forbes vd. (2016) makalesinde, Brezilya'daki vergi artışlarının, dört farklı ülke grubu üzerinde yarattığı dışsallıklar incelenmektedir. Birinci grupta Brezilya'nın komşuları olan Latin Amerika ülkeleri, ikinci grupta Brezilya gibi geniş hisse senedi piyasasına sahip olan gelişen piyasa ekonomileri, üçüncü grupta Çin'e yaptığı ihracat hacmi görece fazla olan ülkeler ve dördüncü grupta yakın zamanda sermaye girişlerine kontrol uygulamış olan ülkeler yer almaktadır. Panel regresyon bulgularına göre, Brezilya'nın portföy girişlerine yönelik vergilerindeki artış; yatırımcıların diğer Latin Amerika ülkelerine, nispeten geniş hisse senedi piyasasına sahip olan ülkelere ve Çin'e daha fazla ihracat yapan ülkelere yaptıkları yatırımları artırmalarına yol açıyor. Buna göre Brezilya'daki kontroller, yatırımcıların bu ülkeye bir çeşit benzerlik gösteren ülkelere dönük portföy tahsislerini yükseltmelerine neden olmuştur. Bu sonuçlar, Brezilya'nın kontrollerinin, söz konusu ülkelerde aşırı 1sınma, yerli paranın değer kazancı ve finansal kırılganlık gibi riskleri yükselttiği anlamına geliyor. Diğer taraftan Brezilya'nın bu vergilerindeki artış, yatırımcıların sermaye kontrolü uygulama olasılığının yüksek olduğu düşünülen ülkelere yaptıkları yatırımları azaltmalarına sebep oluyor. Buna göre Brezilya'daki kontroller, ironik bir şekilde, sermaye kontrollerini kullanma olasılığının yüksek olduğu düşünülen ülkelerde söz konusu riskleri azaltmıştır. Kısacası, Brezilya'da uygulanan kontroller, bazı ülkeler için olumsuz dışsallıklara yol açarken, başka bazı ülkelerde olumlu dışsallıklara neden olmuştur.

Jongwanich (2019) çalışması da, sermaye kontrollerinin diğer ülkelerde hem olumlu hem de olumsuz dışsallıklara yol açabileceğini göstermektedir. Buna göre, Doğu Asya bölgesinde herhangi bir ülkede doğrudan yatırım girişlerine uygulanan kısıtlamalar, bölgedeki başka bir ekonomiye doğrudan yatırım girişini artırmaktadır. Sermaye girişlerinin diğer bileşenleri için (hisse senedi, borç senedi ve diğer yatırımlar) bir ülkedeki giriş kısıtlamaları, diğer ekonomilere sermaye girişini azaltmaktadır. Öte yandan hisse senedi çıkışları üzerindeki kontroller, komşu ekonomilerde sermaye girişini artırırken; diğer üç bileşene dönük çıkış kontrolleri, başka ülkelerde sermaye girişlerini azaltmaktadır. Dolayısıyla Doğu Asya'da sermaye kısıtlamalarının diğer ekonomiler üzerindeki olumlu veya olumsuz yayılma etkileri, akımların hangi bileşenlerine kontrol uygulandığına bağlı olarak değişmektedir.

Giordani vd. (2017), 78 gelişmekte olan ülkenin 1995-2009 yılları arasındaki verilerini kullanarak, giriş kontrollerinin brüt sermaye girişleri üzerindeki etkilerini panel regresyon ve probit model aracılığıla araştırmaktadır. Çalışmada ülkeler coğrafi yakınlık, ihracat uzmanlaşması ve getiri-risk düzeylerine göre gruplara ayrilıyor. Ulaşılan bulgular, giriş kontrollerinin benzer risk düzeylerine sahip olan ülkeler üzerinde güçlü ve anlamlı şekilde olumsuz yayılma etkileri yarattığını gösteriyor. Buna karşın, aynı bölgedeki ülkeler üzerinde yayılma etkilerinin olmadığı tespit ediliyor. Diğer yandan yazarlar, bir ülkedeki kontrollerin benzer özelliklere sahip olan ülkelerde bir politika tepkisine yol açma olasılığını da tahmin ediyorlar. Bulgulara göre, bir ülkedeki giriş kontrollerinin uygulanma olasılığ 1 , diğer ülkelerdeki sermaye kontrollerinden etkilenmiyor. Kısacası, sermaye kontrollerinin diğer ülkelerde güçlü olumsuz yayılma etkileri yarattı̆̆ı, fakat bunların politika tepkisine yol açmadığı gösteriliyor.

Pasricha vd. (2018) çalışmasında, Küresel Kriz öncesinde ve sonrasında sermaye kontrollerinin yayılma etkileri incelenmektedir. 16 gelişmekte olan ülkenin verileri kullanılarak yapılan panel yapısal VAR analizi sonucunda; bir ülkede uygulanan giriş kontrollerinin, diğer ülkelerin para birimleri üzerinde yukarı yönlü bask1 oluştururken, diğer ülkelere yönelik brüt sermaye girişlerini de artırdığı bulunuyor. Ayrıca küresel likiditenin bol olduğu Kriz sonrası dönemde yayılma etkilerinin, bölgeleri aşarak yaygınlaştığ 1 ve daha da güçlendiği bulgusuna ulaş1lyyor. Üstelik bu yayılma etkilerine maruz kalan ülkelerin, diğer ülkelerin kontrollerine tepki olarak kendi giriş kontrollerini sıkılaştırdığına dair kanıtlar da bulunuyor. Sonuç olarak yazarlar, sermaye kontrollerinin güçlü yayılma etkilerine sahip olabileceğini öne sürüyorlar.

Buna karşın Boero vd. (2019), Latin Amerika bölgesi hariç sermaye kontrollerinin başka ülkeler üzerinde yayılma etkileri yarattığına dair çok az kanıt olduğunu ileri sürmektedir. Söz konusu çalışmada 42 ülkenin 1988:Q4-2010:Q4 dönemine ait verileri kullanılarak bir global VAR modeli tahmin ediliyor. Ulaşılan sonuçlar, Latin Amerika'nın en geniş hisse senedi ve borç piyasalarına sahip olan Brezilya'da ve Meksika'da sermaye giriş kontrollerindeki sıkılaşmanın, bölgedeki diğer ülkelere dönük sermaye girişlerinde artışlara yol açtığını gösteriyor. Fakat örnekleme dâhil edilen diğer ülkelerin çoğunda, sermaye kontrollerinin yayılma etkilerine dair güçlü bir kanıt bulunamıyor. Yazarlara göre bu sonuçlar, sermaye kontrollerinin hiçbir zaman dışsallıklar yaratmayacağını göstermese de, kontrollerinin yol açacağı dışsallıkların çok geniş olmadığına işaret ediyor. Yazarlar ayrıca, sermaye kontrollerinin uygulayıcı ülke üzerindeki etkilerinin en iyi olasılıkla geçici olabileceğini, dolayısıyla kontrollerin ülkeleri uluslararası finansal sistemden sürekli bir biçimde yalıtıcı etkisinin bulunmadığını ifade ediyorlar.

Sermaye kontrollerinin yayılma etkilerini inceleyen çalışmalarda ulaşılan sonuçlar şöyle özetlenebilir. Lambert vd. (2013), Forbes vd. (2016) ve Boero vd. (2019) Latin Amerika'da, Jongwanich (2019) ise Asya'da bölge içi yayılma etkileri bulunduğunu kanıtlıyorlar. Pasricha vd. (2018), yayılma etkilerinin sadece bölge 
içiyle sınırlı olmadığını gösteriyor. Giordani vd. (2017) yayılma etkilerinin bölge içinden ziyade, benzer risk düzeylerine sahip olan ülkeler arasında ortaya çıktı̆̆ını savunuyor. Diğer taraftan Pasricha vd. (2018) sermaye kontrollerinin başka ülkelerde politika tepkisine yol açtığını savunurken, Giordani vd. (2017) politika tepkisine dair böyle bir bulguya ulaşamıyor.

\section{SONUÇ}

Son y1llarda sermaye kontrollerine ilişkin tartışmalar yeniden canlanmıştır. Günümüzün artan finansal entegrasyon ortamında, büyük ölçüde küresel faktörler tarafından yönlendirilen uluslararası sermaye akımları, gelişmekte olan ülkelerde istikrar bozucu etkiler yaratmaktadır. Küresel Kriz sonrasında birçok gelişmekte olan ülke, makroekonomik ve finansal istikrar kaygılarıyla sermaye kontrollerini (ve/veya diğer makro ihtiyati politikaları) uygulamıştır. Aynı dönemde, oynak sermaye akımlarından kaynaklanan riskleri yönetmek üzere, sermaye kontrollerinin ikinci en iyi politika aracı olarak kullanılabileceğini öneren teorik görüşler de yaygınlaşmıştır. Yeni teorik literatür, konjonktür karşıtı uygulanacak ihtiyati sermaye kontrollerinin, çıktıdaki ve finansal değişkenlerdeki dalgalanmaları hafifletmek suretiyle refah artırıcı etki yaratabileceğini öngörmektedir. Diğer taraftan IMF de, sermaye kontrollerinin belirli koşullar altında meşru bir politika aracı olarak kullanılabileceğini kabul ederek, önceki (karşı) duruşunu yumuşatmış görünmektedir.

Küresel Kriz sonrasında, sermaye kontrollerine dair ampirik literatür de genişlemektedir. Söz konusu literatür dört konu üzerinde yoğunlaşmaktadır. Birincisi, sermaye kontrollerinin ihtiyati amaçla mı yoksa merkantilist amaçla $\mathrm{m} ı$ uygulandığı konusudur. Bu konuda yapılan çalışmalar, sermaye kontrollerinin hem ihtiyati hem de merkantilist amaçla kullanıldığını; fakat Kriz sonrası dönemde ihtiyati güdünün payının arttığını göstermektedir. İkincisi, sermaye kontrollerinin konjonktür karşıtı kullanılıp kullanılmadığı sorusudur. Ampirik çalışmalarda, sermaye kontrollerinin üretimdeki dalgalanmalara, ticaret hadlerine veya finansal istikrar kaygılarına tepki olarak nadiren değiştirildiği; dolayısıyla kontrollerin genellikle konjonktür karşıtı kullanılmadığ konjonktür karşıtı biçimde uygulamayı başardıkları tespit edilmektedir. Üçüncüsü, sermaye kontrollerinin belirli hedeflere ulaşmada etkili olup olmadığı hususudur. Küresel Kriz öncesi yapılan ampirik çalışmalarda kontrollerin; genellikle sermaye akımlarının bileşimini değişmede ve para politikası özerkliğini artırmada etkili olduğu bulunurken, sermaye akımlarının toplam hacmi ve reel döviz kuru üzerinde yarattığı etkilere dair karmaşık bulgulara ulaşılmaktaydı. Kriz sonrasında yapılan çalışmalarda sermaye kontrollerinin, akımların bileşimi ve parasal özerklik üzerinde etkili sonuçlara yol açtığı teyit edilmektedir. Diğer taraftan Kriz sonrası literatürde, sermaye kontrollerinin toplam sermaye akımları ve döviz kuru üzerinde etkili olabileceğini kanıtlayan çalışmaların payı nispeten yüksek olmakla birlikte, bulguların kesin bir çıkarıma yol açıp açmadığı konusu tartışmalı görünmektedir. Bunun yanında son yıllarda sermaye kontrollerinin, finansal kırılganlıkları ve makroekonomik oynaklıkları hafifletmede etkili olabileceğini ispatlayan çalışmalar da göze çarpmaktadır. Dördüncüsü ise, sermaye kontrollerinin başka ülkeler üzerinde yaratması muhtemel yayılma etkilerinin araştırılmasıdır. Yapılan araştırmalarda, sermaye kontrollerinin diğer ülkeler üzerinde olumsuz yayılma etkilerine yol açabileceği gösterilmektedir.

Bütün bu sonuçlar, ülkelerin sermaye kontrollerini belirli hedeflere ulaşmak için etkili bir biçimde kullanılabileceklerini; fakat kontrollerin yayılma etkilerinden doğan küresel refahı azaltıcı sonuçların hafifletilebilmesi için, ülkeler arasında politika koordinasyonuna gerek olduğunu göstermektedir. Ayrıca sermaye girişlerinin belirli bileşenlerine yönelik kontrollerin, diğer bileşenler üzerinde azaltıcı ya da artırıcı etkilere yol açabileceğine dair bulguların; sermaye kontrollerinin belirli bileşenleri hedefleme kabiliyeti ve sermaye kontrollerinden kaçınma yolları konularında tartışmaların sürmesine yol açtığı söylenebilir. İlave olarak sermaye kontrollerinin etkilerinin, ülkelerin kontrolleri uygulama kabiliyetini yansitan kurumsal kalitelerine ve kontrolleri ne ölçüde sıkı uyguladıklarına bağlı olduğu yönündeki bulguların da, kontrollerin etkililiğine ilişkin görüş ayrılıklarına sebep olduğunu belirtmek gerekir. 


\section{KAYNAKÇA}

Ahmed, S. \& Zlate, A. (2014). “Capital Flows To Emerging Market Economies: A Brave New World?”. Journal of International Money and Finance, 48, 221 - 248.

Aizenman, J. \& Binici, M. (2016). "Exchange Market Pressure in OECD and Emerging Economies: Domestic vs. External Factors and Capital Flows in the Old and New Normal". Journal of International Money and Finance, 66, 65-87.

Baba, C. \& Kokenyne, A. (2011). "Effectiveness of Capital Controls in Selected Emerging Markets in the 2000s". IMF Working Paper, WP/11/281.

Benigno,G., Chen, H., Otrok, C., Rebucci, A. \& Young, E.R. (2013). "Financial Crises and Macro-prudential Policies". Journal of International Economics, 89(2), 453-470.

Benigno, G., Chen, H., Otrok, C., Rebucci, A. \& Young, E.R. (2014). "Capital Control or Exchange Rate Policy? A Pecuniary Externality Perspective". CEPR Discussion Paper, No:9936.

Bernanke, B., Gertler, M. \& Gilchrist, S. (1999).” The Financial Accelerator in a Quantitative Business Cycle Framework". Taylor, J. \& Woodford, M. içinde, Handbook of Macroeconomics, Amsterdam, Elsevier Science, 1341-1393.

Bianchi, J. (2011). "Overborrowing and Systemic Externalities in the Business Cycle”. American Economic Review, 101, $3400-3426$.

Bianchi, J. \& Mendoza, E. (2010). “Overborrowing, Financial crises and Macro-prudential Taxes”. NBER Working Paper, No.16091.

Boero, G., Mandalinci, Z. \& Taylor, M. (2019). "Modelling Portfolio Capital Flows in a Global Framework: Multilateral Implications of Capital Controls". Journal of International Money and Finance, 90, 142-160.

Bruno, V. \& Shin, H.S. (2014). "Assessing Macroprudential Policies: Case of South Korea”. Scandinavian Journal of Economics, 116 (1), 128-157.

Bruno, V., Shim, I. \& Shin, H. S. (2017). "Comparative Assessment of Macroprudential Policies". Journal of Financial Stability, 28, 183-202.

Cardoso, E. \& Goldfajn, I. (1998). "Capital Flows to Brazil: The Endogeneity of Capital Controls". IMF Staff Papers, 45(1), 161-202.

Chamon, M. \& Garcia, M. (2016). "Capital Controls in Brazil: Effective?”. Journal of International Money and Finance, $61,163-187$.

Costinot, A, Lorenzoni, G. \& Werning, I. (2014). "A Theory of Capital Controls as Dynamic Terms-of-trade Manipulation". Journal of Political Economy, 122(1), 77-128.

Dell'Erba, S. \& Reinhardt, D. (2015). "FDI, Debt and Capital controls". Journal of International Money and Finance, 58, 29-50.

Dooley, M. Folkerts-Landau, D. \& Garber, P. (2004). "The Revived Bretton Woods System”. International Journal of Finance and Economics, 9(4), 307-313.

Dooley, M. Folkerts-Landau, D. \& Garber, P. (2014). "The Revived Bretton Woods System's First Decade". NBER Working Paper, No:20454.

Eichengreen B. \& Rose, A. (2014). "Capital Controls in the 21st Century". Journal of International Money and Finance, $48,1-16$.

Engel, C. (2016). "Macroprudential Policy Under High Capital Mobility: Policy Implications from an Academic Perspective". Journal of the Japanese and International Economies, 42, 162-172

Erten, B. \& Ocampo, J.A. (2017). "Macroeconomic Effects of Capital Account Regulations". IMF Economic Review, 65(2), 193-240.

Farhi, E. \& Werning, I. (2012). "Dealing With the Trilemma: Optimal Capital Controls with Fixed Exchange Rates". NBER Working Paper, No:18199.

Fernandez, A., Rebucci, A. \& Uribe, M. (2015). “Are Capital Controls Countercyclical?”. Journal of Monetary Economics, 76, 1-14.

Fernandez, A., Klein, M.W., Rebucci, A., Schindler, M. \& Uribe, M. (2015). Capital control measures: a new dataset. NBER Working Paper, No. 20970.

Forbes, K.J., Fratzscher, M. \& Straub, R. (2015). "Capital-flow Management Measures: What are They Good for?”. Journal of International Economics, 96, S76-S97.

Forbes, K.J., Fratzscher, M., Kostka, T. \& Straub, R. (2016). "Bubble thy Neighbour: Portfolio Effects and Externalities from Capital Controls". Journal of International Economics, 99, 85-104.

G20 (2011). G20 Coherent Conclusions for the Management of Capital Flows Drawing on Country Experiences, as Endorsed by G20 Finance Ministers and Central Bank Governors, October 15, 2011.

Gertler, M., Gilchrist, S. \& Natalucci, F.M. (2007). "External Constraints on Monetary Policy and the Financial Accelerator". Journal of Money, Credit and Banking, 39(2-3), 295-330.

Ghosh, A.R., Qureshi, M.S. \& Sugawara, N. (2014). "Regulating Capital Flows at Both Ends: Does it work?". IMF Working Paper, WP/14/188.

Giordani, P.E., Ruta, M., Weisfeld, H. \& Zhu, L. (2017). "Capital Flow Deflection”. Journal of International Economics, $105,102-118$. 
Gupta, P. \& Masetti, O. (2018). “Capital Flow Measures: Structural or Cyclical Policy Tools?”. World Bank Policy Research Working Paper, No:8418.

Heathcote, J. \& Perri, F. (2016). “On the Desirability of Capital Controls”. IMF Economic Review, 64(1), 75-102.

IMF (2012). The Liberalization and Management of Capital Flows: An Institutional View. International Monetary Fund, Washington.

Jeanne, O. (2012). “Capital Flow Management”. American Economic Review, Pap. Proc. 102: 203-206.

Jeanne, O. \& Korinek, A. (2013). "Macroprudential Regulation versus Mopping up After the Crash". NBER Working Paper, No.18675.

Jongwanich, J. (2019). Capital controls in emerging East Asia: How do they affect investment flows?. Journal of Asian Economics, 62, 17-38.

Kaminsky, G.L., Reinhart, C.M. \& Vegh, C.A. (2004). "When it Rains, it Pours: Procyclical Capital Flows and Macroeconomic Policies". NBER Working Paper, No.10780.

Kiyotaki, N. \& Moore, J. (1997). "Credit Cycles". Journal of Political Economy, 105(2), 211-248.

Korinek, A. (2011). "The New Economics of Prudential Capital Controls: A Research Agenda”. IMF Economic Review, 59(3), 523-561.

Korinek, A. \& Sandri, D. (2016). “Capital Controls or Macroprudential Regulation?”. Journal of International Economics, 99, S27-S42.

Lambert, F., Ramos-Tallada, J. \& Rebillard, C. (2013). “Capital Controls and Spillover Effects: Evidence from LatinAmerican Countries". Banque de France Working Paper, No:357.

Li, J. \& Rajan, R.S. (2015). “Do Capital Controls Make Gross Equity Flows to Emerging Markets Less Volatile?”. Journal of International Money and Finance, 59, 220-244.

Magud, N., Reinhart, C. \& Rogoff, K. (2011). "Capital Controls: Myth and Reality- A Portfolio Balance Approach". NBER Working Paper, No. 16805.

Mendoza, E. G. (2010). "Sudden Stops, Financial Crises, and Leverage”. The American Economic Review, 100(5), 19411966.

Montiel, P. \& Reinhart, C. (1999). "Do Capital Controls and Macroeconomic Policies Influence the Volume and Composition of Capital Flows? Evidence from the 1990s". Journal of International Money and Finance, 18(4), 619-635.

Ostry, J.D., Ghosh, A.R., Habermeier, K., Chamon, M., Qureshi, M. \& Reinhardt, D. (2010). “Capital Inflows: The Role of Controls". IMF Staff Position Note, 10/04.

Ostry, J.D., Ghosh, A.R., Chamon, M. \& Qureshi, M. (2012). “Tools for Managing Financial Stability Risks from Capital Inflows". Journal of International Economics, 88(2), 407-421.

Pasricha, G. (2012). "Recent Trends in Measures to Manage Capital Flows in Emerging Economies". North American Journal of Economics and Finance, 23, 286- 309.

Pasricha, G. (2017). "Policy Rules for Capital Controls". Bank of Canada Staff Working Paper, No:42.

Pasricha, G., Falagiarda, M., Bijsterbosch, M. \& Aizenman, J. (2018). "Domestic and Multilateral Effects of Capital Controls in Emerging Markets”. Journal of International Economics, 115, 48-58.

Reinhart, C.M. ve Rogoff, K.S. (2009). Bu Defa Farklı: Finansal Çılgınlığın 800 Yıllık Tarihi. .NTV Yayınları, İstanbul.

Schmitt-Grohe, S. \& Uribe, M. (2016). "Downward Nominal Wage Rigidity, Currency Pegs, and Involuntary Unemployment". Journal of Political Economy, 124(5), 1476-1514.

Van der Laan, C. R., Cunha, A. M., \& Lelis, M. T. C. (2017). On the effectiveness of capital controls during the Great Recession: The Brazilian experience (2007-2013). Journal of Post Keynesian Economics, 40(2), 203-222.

You, Y., Kim, Y. \& Ren, X. (2014). Do Capital Controls Enhance Monetary Independence?. Review of Development Economics, 18(3), 475-489.

Zeev, N.B. (2017). "Capital Controls as Shock Absorbers”. Journal of International Economics, 109, 43-67.

Zhang, L. \& Zoli, E. (2016). "Leaning Against the Wind: Macroprudential Policy in Asia”. Journal of Asian Economics, $42,33-52$. 